University of Wollongong

Research Online

Faculty of Engineering and Information

Faculty of Engineering and Information

Sciences - Papers: Part A

Sciences

$1-1-2016$

\title{
Modelling of geocell-reinforced subballast subjected to cyclic loading
}

\author{
M. Mahdi Biabani \\ University of Wollongong, mmb958@uowmail.edu.au \\ Buddhima Indraratna \\ University of Wollongong, indra@uow.edu.au \\ Ngoc Trung Ngo \\ University of Wollongong, trung@uow.edu.au
}

Follow this and additional works at: https://ro.uow.edu.au/eispapers

Part of the Engineering Commons, and the Science and Technology Studies Commons

Research Online is the open access institutional repository for the University of Wollongong. For further information contact the UOW Library: research-pubs@uow.edu.au 


\title{
Modelling of geocell-reinforced subballast subjected to cyclic loading
}

\begin{abstract}
This paper presents the experimental and numerical studies of geocell-reinforced subballast subjected to cyclic loading. A series of laboratory experiments were conducted using a large-scale prismoidal triaxial apparatus that was subjected to relatively low confining pressures of $\sigma^{\prime} 3=10-30 \mathrm{kPa}$ and a frequency of $f$ $=10 \mathrm{~Hz}$. Numerical simulations were performed using the commercial finite element package ABAQUS in three dimensions to realistically model cellular confinement, and to study the effectiveness of geocell reinforcement on subballast. A cyclic loading with a periodic and positive full-sine waveform was adopted to model the geocell-reinforced subballast, which is similar to the load carried out in the laboratory. The results of numerical modelling agreed well with the experimental data, and showed that geocell could effectively decrease the lateral and axial deformations of the reinforced subballast. The numerical model was also validated by the field data, and the results were found to be in good agreement, indicating that the proposed model was able to capture the load-deformation behaviour of geocell-reinforced subballast under cyclic loading. A parametric study was also carried out to evaluate the effect of the subballast strength and geocell stiffness on the mobilized tensile strength in the geocell mattress. It was found that the maximum mobilized tensile stress occurs on the subballast with the lowest degree of stiffness. Also the results revealed that lateral displacement decreased further by increasing geocell stiffness, and geocell with a relatively low stiffness performs very well compared to the geocell with a higher stiffness.
\end{abstract}

\section{Disciplines}

Engineering | Science and Technology Studies

\section{Publication Details}

Biabani, M. Mahdi., Indraratna, B. \& Ngo, N. (2016). Modelling of geocell-reinforced subballast subjected to cyclic loading. Geotextiles and Geomembranes, 44 (4), 489-503. 
2
M. Mahdi Biabani, PhD, MEng, BEng

Research Assistant, Centre for Geomechanics and Railway Engineering, University of Wollongong, Wollongong City, NSW 2522, Australia; ARC Centre for Excellence for Geotechnical Science and Engineering, Australia.

Buddhima Indraratna, PhD (Alberta), FTSE, FIEAust., FASCE, FGS.

Research Director, Professor of Civil Engineering, Centre for Geomechanics and Railway Engineering, University of Wollongong, Wollongong, NSW 2522, Australia. ARC Centre for Excellence for Geotechnical Science and Engineering, Australia.

Ngoc Trung Ngo, PhD, MEng, BEng Lecturer, School of Civil, Mining and Environmental Engineering, University of Wollongong, Wollongong City, NSW 2522, Australia; ARC Centre for Excellence for Geotechnical Science and Engineering, Australia.

Author for correspondence:

Prof. B. Indraratna

Faculty of Engineering and Information Sciences

University of Wollongong

Wollongong, NSW 2522

Australia.

Ph: +61242213046

Fax: +61 242213238

Email: indra@uow.edu.au 


\title{
Modelling of geocell-reinforced subballast subjected to cyclic loading
}

\author{
M. Mahdi Biabani ${ }^{1}$, Buddhima Indraratna ${ }^{2}$ and Ngoc Trung Ngo $^{3}$
}

\author{
${ }^{1}$ Research Assistant, Centre for Geomechanics and Railway Engineering, Faculty of \\ Engineering, University of Wollongong, Wollongong City, NSW 2522, Australia; ARC \\ Centre for Excellence for Geotechnical Science and Engineering, Australia. \\ Email:mmb958@uowmail.edu.au
}

\author{
${ }^{2}$ Research Director, Professor of Civil Engineering, Centre for Geomechanics and Railway \\ Engineering, University of Wollongong, Wollongong, NSW 2522, Australia. ARC Centre for \\ Excellence for Geotechnical Science and Engineering, Australia. \\ Email: indra@uow.edu.au, Ph: +61242213046 Fax: +61 242213238 \\ ${ }^{3}$ Lecturer, School of Civil, Mining and Environmental Engineering, University of \\ Wollongong, Wollongong City, NSW 2522, Australia; ARC Centre for Excellence for \\ Geotechnical Science and Engineering, Australia. \\ Email: trung@uow.edu.au, Ph: +61 242214892 Fax: +61 242213238
}

ABSTRACT: This paper presents the experimental and numerical studies of geocellreinforced subballast subjected to cyclic loading. A series of laboratory experiments were conducted using a large-scale prismoidal triaxial apparatus that was subjected to relatively low confining pressures of $\sigma_{3}^{\prime}=10-30 \mathrm{kPa}$ and a frequency of $f=10 \mathrm{~Hz}$. Numerical simulations were performed using the commercial finite element package ABAQUS in three dimensions to realistically model cellular confinement, and to study the effectiveness of geocell reinforcement on subballast. A cyclic loading with a periodic and positive full-sine waveform was adopted to model the geocell-reinforced subballast, which is similar to the load carried out in the laboratory. The results of numerical modelling agreed well with the experimental data, and showed that geocell could effectively decrease the lateral and axial deformations of the reinforced subballast. The numerical model was also validated by the field data, and the results were found to be in good agreement, indicating that the proposed model was able to capture the load-deformation behaviour of geocell-reinforced subballast under cyclic loading. A parametric study was also carried out to evaluate the effect of the 
subballast strength and geocell stiffness on the mobilized tensile strength in the geocell mattress. It was found that the maximum mobilized tensile stress occurs on the subballast with the lowest degree of stiffness. Also the results revealed that lateral displacement decreased further by increasing geocell stiffness, and geocell with a relatively low stiffness performs very well compared to the geocell with a higher stiffness.

72

KEYWORDS: Geosynthetics, Geocell reinforcement, subballast, cyclic loading, plane strain, numerical modelling

75

\section{Introduction:}

Railway networks are one of the major transport systems used for carrying passengers, and transporting freight and bulk commodities between major mines and ports in many countries worldwide. Considering an acceptable ride quality, relatively low cost, and growing demand from industry and commuters, railways have become more popular than other modes of transportation. Nevertheless, the sustainable development of rail infrastructure requires a significant amount of cost associated with track maintenance and rehabilitation of track substructure (Indraratna et al. 2013). However, to compete with other transportation modes and meet the ever growing demand for public and freight transport, the railway industry will face challenges to improve the track operational efficiency and decrease maintenance and infrastructure costs. The foundation of a conventional ballasted track consists of granular material layers that help to transmit and distribute the induced cyclic load to the underlying subgrade at an acceptable or controlled stress level (Suiker et al. 2005; Selig and Waters 1994). To date, reinforcing track substructure using a planar reinforcement is commonly deployed as it has been proven to reduce the axial and lateral deformation of ballast and 
92 (Ngo et al. 2014; Indraratna et al. 2011; Kwon and Tutumluer 2009; Atalar et al. 2001). Past studies have shown that cellular reinforcement can provide much better lateral confinement to infill granular soils than planar reinforcements (Indraratna et al. 2015, Hegde and Sitharam 2015, Huang et al. 2011, Han et al. 2011). The performance of geocell mattress in stabilizing different types of infill soils subjected to monotonic loading has been investigated in several studies (Biabani and Indraratna 2015; Wang et al. 2013; Tafreshi et al. 2012; Yang et al. 2010; Pokharel et al. 2010; Saride et al. 2009). A summary of research outcomes of selected past studies is given in Table 1. In addition, there are a few studies available, which have investigated the performance of granular material in plane-strain condition (Radampola et al. 2008; Wanatowski et al. 2008; Radampola 2006; Peters et al. 1988). However, understanding the performance of geocell reinforcement under cyclic loading is the key requirement, which is needed for its design and application in ballasted rail tracks.

The development of a numerical model is inevitable in order to establish proper design guidelines based on safety and economic considerations. Considering the computational effects involved, a two-dimensional (2D) model often become more popular than a threedimensional (3D) model for plane strain conditions (Hedge and Sitharam 2013; Mehdipour et al. 2013; Yu and Sloan 1997). An equivalent composite approach has often been used to model geocell-reinforced soil in a 2D environment by modelling the reinforced soil as a new layer with improved strength and stiffness (Hegde and Sitharam 2013; Latha and Somwanshi 2009; Bathurst and Knight 1998). However, a 2D model cannot accurately capture the additional confinement developed through circumferential strains due to the complex shape of the geocell mattress (with its honeycomb like structure). Very limited number of studies have been investigated the performance of geocell-reinforced soil in a 3-dimensional framework under monotonic loading (Hegde and Sitharam, 2014). Also, to the authors 
117 knowledge, there has only been limited research carried out on the effect of geocell mattress

118 on railway substructure, where the benefits of geocell subjected to cyclic loading has not

119 been studied in details either in laboratory or numerical modelling (Leshchinsky and Ling 120 2013a; Wang et al. 2013; Mehdipour et al. 2013; Tavakoli Mehrjardi et al. 2012; Choudhury 121 2009). The development of a numerical model that has been calibrated accurately by

122 laboratory and field measurements is thereby inevitable to understand the performance of 123 geocell-reinforced subballast and to propose a proper design guideline for ballasted rail track,

124 while considering the confinement effect of the geocell. An attempt was made in this study to 125 carry out large-scale cubical tests of geocell-reinforced subballast and to develop a 3D 126 numerical model to simulate the composite system, and capture the actual geometry of 127 geocell pockets and its additional confinement to the subballast.

128

129

\section{Experimental study}

130 In order to obtain a more realistic understanding of subballast under cyclic loading, 131 experimental work was conducted to mimic the true field conditions, where the intermediate stress differs from the minor principal stress $\left(\sigma_{2}^{\prime} \neq \sigma_{3}^{\prime}\right)$. As a result, the large-scale prismoidal

133 triaxial apparatus (800 mm long, $600 \mathrm{~mm}$ wide and $600 \mathrm{~mm}$ high) was designed and built at

134 the University of Wollongong (Fig.1), and it was used to investigate the stress-strain behaviour of the unreinforced and geocell-reinforced subballast subjected to cyclic loading

136 (Indraratna et al. 2015). The area of the test specimen in the prismoidal triaxial chamber was 137 selected based on Australian standard gauge for heavy haul track. Therefore, in the direction 138 perpendicular to sleepers (tie), $400 \mathrm{~mm}$ symmetrically on each side of one rail (i.e. $800 \mathrm{~mm}$ ) 139 was taken, and this is equal to $1 / 3$ of the total sleeper length (l) of $2400 \mathrm{~mm}$ (also termed as 140 effective sleeper length byJeffs and Tew 1991); and (ii) in the direction parallel to sleeper 141 (tie), a distance equalling the sleeper spacing of $600 \mathrm{~mm}$ was considered (Fig. 2a). This 
142 explains the plan area of $800 \mathrm{~mm} \times 600 \mathrm{~mm}$ of the test specimen. The subballast material had

143 a total depth of $450 \mathrm{~mm}$, of which the upper 150mm was stabilised by geocell. The material

144 for subballast used in this study was a locally available crushed basalt, collected from a

145 quarry near Wollongong (NSW, Australia). The particle size distribution adopted for the

146 subballast was within the rail industry specified range $\left(D_{50}=3.3 \mathrm{~mm}, D_{\max }=19 \mathrm{~mm}, D_{\min }=\right.$

$\left.1470.075 \mathrm{~mm}, C_{u}=16.3, C_{c}=1.3, \gamma_{d}=19 \mathrm{kN} / \mathrm{m}^{3}\right)$. A predetermined mass of subballast was

148 placed inside the cubical box in several layers and compacted in dry conditions using a

149 vibratory hammer to achieve a relative density $\left(D_{R}\right)$ of about $77 \%$, which is representative of

150 the density of subballast in the field $\left(\gamma_{\text {bulk }}=20.5 \mathrm{kN} / \mathrm{m}^{3}\right)$. A geocell mattress was placed onto

151 the surface of the subballast. All the specimens were prepared until the layer of subballast

152 reached a final height of $450 \mathrm{~mm}$. A geocell mattress made from polyethylene materials, that

153 was connected at the joints to create a three-dimensional cellular form (i.e. depth $=150 \mathrm{~mm}$,

154 ultimate tensile strength $=9.5 \mathrm{kN} / \mathrm{m}$ (ASTM D4885), thickness $=1.3 \mathrm{~mm}$, density $=950$

$155 \mathrm{~kg} / \mathrm{m}^{3}$ ) was used.

156

157 The experiments were conducted under plane strain condition, where any lateral movement in 158 the longitudinal direction (parallel to the track) was restricted ( $\varepsilon_{2}=0$ ). The walls were

159 allowed to move laterally in the direction parallel to the sleeper (or tie) ( $\varepsilon_{3} \neq 0$ ), to simulate a

160 long straight section of track. The laboratory tests were conducted in a stress-controlled

161 manner, where the magnitudes of the cyclic stresses were computed based on 30 tons/axle

162 load (Jeffs and Tew 1991, Atalar et al. 2001). To examine the effects confining pressure on 163 the behaviour of subballast, cyclic drained triaxial tests were conducted at confining

164 pressures $\left(\sigma_{3}^{\prime}\right)$ of $5,10,15,20,30 \mathrm{kPa}$ and frequencies $(f)$ of 10,20 , and $30 \mathrm{~Hz}$. During the 165 laboratory experiment, the lateral movement of the vertical walls in the direction of the 
intermediate principle stress $\left(\sigma_{2}^{\prime}\right)$ was prevented by locking the castors (i.e. $\varepsilon_{2}=0$ ), while

167 the vertical walls in the orthogonal (i.e. transverse) direction of minor principle stress ( $\sigma_{3}^{\prime}$ ) 168 were allowed to move laterally. Initially, a monotonic strain-controlled load was applied to the specimen at a rate of $1 \mathrm{~mm} / \mathrm{min}$ until a mean level of cyclic deviator stress was attained. Subsequently, a stress controlled cyclic loading using a positive full-sine waveform was

171 applied to the specimens where a maximum and minimum stress of $q_{\max }=166 \mathrm{kPa}$ and $q_{\min }=$

$17241 \mathrm{kPa}$ was used to simulate subballast under a heavy haul freight network operating in NSW

173 (Indraratna et al. 2015).

174 The laboratory outcomes revealed that confining pressure and frequency have a significant impact on the behaviour of the granular material under cyclic loading. The laboratory results confirmed that under cyclic loading, geocell mattress can offer additional confinement $\left(\Delta \sigma_{3}^{\prime}\right)$ to the infill material (i.e. other than the confining pressure available from sleepers and shoulder ballast), and help to decrease the axial and lateral deformations (Indraratna et al.

179 2015). Also it is noted that due to cyclic loading, the magnitude of $\Delta \sigma_{3}^{\prime}$ would be increase as

180 the number of load cycle increases and when the densely compacted infill material dilates and 181 thereby increases the magnitude of hoop stress. A summary of the key aspects of experimental outcomes can be brieftly summarised as: (i) the mobilised hoop stress of the geocell pockets is generated as a result of the dilation of the infilled soil during shearing; and (ii) the magnitude of hoop stress varies with the geocell modulus.

\section{Finite element analysis}

187 Model tests were simulated in the finite element method (FEM) where the material properties obtained from laboratory tests and model geometry followed the cubical apparatus carried out in the laboratory $(800 \mathrm{~mm} \times 600 \mathrm{~mm} \times 450 \mathrm{~mm})$, as illustrated in Figs. 2(a \& b). The size of 

the specimen represents the effective sleeper length $(l e=800 \mathrm{~mm})$ and distance between two adjacent sleepers (tie in North America) $(b=600 \mathrm{~mm})$ with a depth of $h=450 \mathrm{~mm}$ (Indraratna et al. 2015; Jeffs and Tew 1991). A cyclic loading stress, caused by a train and exerted beneath the ballast, was applied directly onto the subballast layer, where the loading

194 characteristics were similar to those used in the laboratory. As result, no ballast or sleeper 195 (tie) was considered in this simulation. In the current analysis, a subballast layer was modelled with a depth of $450 \mathrm{~mm}$ to represent variations in the subballast height as measured in the field. One of the limitations of the prismoidal test chamber is that it may not be deep enough to represent the actual subgrade depth in the field, and therefore, the actual measured strains in the prismoidal test chamber with $450 \mathrm{~mm}$ depth may not be truly representative of the field conditions except where the subgrade is rock or very stiff and dense gravel.

\subsection{Material properties}

An elasto-plastic material with non-associative behaviour was used to model the subballast.

To capture the elasto-plastic behaviour of subballast, the Drucker-Prager yield criterion was adopted in this analysis. The shear strength parameters (i.e., $\phi, \psi$ ) could be obtained using appropriate triaxial equipment (Indraratna et al. 2015; Bolton 1986). A linear elastic-perfectly plastic material was used to model the geocell mattress. The elastic properties of the geocell strips were determined in the laboratory and then incorporated into a finite element model in ABAQUS. A hexagonal shape was used to model the geometry of the geocell pockets, as it is

210 similar to the actual curvature of the geocell mattress used in the laboratory. Since, subballast 211 is never clean or perfectly granular, as it is always contaminated with small amount of 212 cohesive clay. The actual measured cohesion values from large-scale triaxial tests (depending 213 upon the extent of clay fouling) can sometimes exceed $5 \mathrm{kPa}$ as shown by Tennekoon (2012).

214 Accordingly, a small value of cohesion $(2 \mathrm{kPa})$ was used in the simulations to improve 
numerical stability and to ensure that the model converged in a reasonable computation time while not critically affecting the results. A summary of the material properties used in the analysis is provided in Table 2. Considering the extensive computation time required to run a model under cyclic loading, the simulations were carried out up to 10,000 cycles, where most of the subballast deformation had already occurred, as seen in the laboratory.

\subsection{Boundary conditions}

To simulate field track conditions, lateral displacement in the direction of the intermediate principal stress $\sigma_{2}^{\prime}$ (i.e. parallel to the tracks) was constrained $\left(\varepsilon_{2}=0\right.$ ). Meanwhile, the model was allowed to move in the direction of the major principal stress $\sigma_{1}^{\prime}$ (i.e. vertical settlement) and the minor principal stresses $\sigma_{3}^{\prime}$ (i.e. parallel to the sleepers) $\left(\varepsilon_{1}, \varepsilon_{3} \neq 0\right)$. The base of the model was restricted to any displacement, as shown in Fig. 3(a). To obtain an optimum size mesh for the model, a sensitivity analysis of mesh density was carried out for a model with a varying number of elements. Vertical settlements of the geocell-reinforced subballast obtained from the models with different numbers of elements were compared at a load cycle of $N=1000$ (Fig. 3b). The results showed that by increasing the number of elements, the vertical settlement $\left(S_{V}\right)$ increases, and when the number of elements is beyond 9,000, the increment in vertical settlement can be negligible. Based on this preliminary finding, a FE model with 9380 elements with 12624 nodes (ABAQUS) was selected to simulate the geocell-reinforced subballast. The type of elements chosen were C3D8R (i. e. eight-node reduced integration element). The interaction between subballast and geocell strips was modelled with contact elements, including the hard normal contact as used by Leshchinsky and Ling (2013a). Given the highly random nature of particle orientations within the subballast assembly, it was assumed that the angle of shearing resistance between the aggregates and geocell mattress was isotropic, considering that the membrane texture is 
usually uniform. In the numerical simulation, the contact between the infilled granular soil and geocell wall was modelled as an interface element with a fixed angle of shearing resistance. The interface friction angle $\left(\phi=39^{\circ}\right)$ between the infill and cell wall was determined in the laboratory using large-scale direct shear tests. The direct shear tests were conducted at relatively low normal stress that varied from 1 to $45 \mathrm{kPa}$. As a result, the interface contact for both horizontal and vertical direction was modelled by assuming 2/3 of the interface friction angle $\left(\phi=39^{\circ}\right)$.

\subsection{Loading conditions}

In order to have uniform deformation, initially a constant confining pressure $\left(\sigma_{3}^{\prime}\right)$ was applied to the unit cell prior to cyclic loading to simulate mean pressure due to the geostatic stresses inherent in a railway track. Two loading stages were used to simulate the cyclic loading as conducted in the laboratory. A static load with a magnitude of $\sigma_{\text {mean }}=104 \mathrm{kPa}$ was applied to the top of the specimen in the strain-controlled model. The maximum stress in the cyclic loading pattern was chosen to provide the most possible critical stress that could be applied to the subballast as measured by Indraratna et al (2015), which the details are given in the Appendix. After completing the static loading, a cyclic load was superimposed onto the monotonic loading at different confining pressures, as shown in Fig. 4. During the application of cyclic load, each load cycle was returned to a fully unloaded stage to represent a passing train wheel, where a periodic and positive full sine waveform was considered. The cyclic load was performed in a stress controlled mode with a frequency of $f=10 \mathrm{~Hz}$, where the maximum and minimum load amplitudes were $166 \mathrm{kPa}$ and $41 \mathrm{kPa}$, respectively (Fig. 4) (Indraratna et al. 2015; Jeffs and Tew 1991). Numerical simulation were carried out at relatively low confining pressures $\left(5 \mathrm{kPa} \leq \sigma_{3}^{\prime} \leq 30 \mathrm{kPa}\right)$ to simulate the typical small confinement provided by the shoulder ballast and sleeper (tie) in actual tracks. 


\section{Results and Discussions}

267

\subsection{Vertical settlement}

Figs. 5(a \& b) show the vertical settlement contours for unreinforced and geocell-reinforced subballast subjected to cyclic loading (frequency of $f=10 \mathrm{~Hz}$; confining pressure of $\sigma_{3}^{\prime}=10$ $\mathrm{kPa}$ ) at a load cycle of $N=10,000$. The numerical results indicate that the subballast experiences the highest vertical deformation of about $S_{V}=8.45 \mathrm{~mm}$ under the footing surface (Fig. 5a), and this gradually decreases with the depth, where settlement at a depth of $h=200$ $250 \mathrm{~mm}$ is about $S_{V}=5.28 \mathrm{~mm}$.

However, placing a geocell mattress beneath the footing significantly decreased the magnitude of vertical settlement in the reinforced subballast, where settlement was only $S_{V}=$ $2.57 \mathrm{~mm}$ for the reinforced specimen, compared to $S_{V}=8.45 \mathrm{~mm}$ for the unreinforced specimen [Fig. 5(b)]. Maximum settlement occurred close to the edge of the specimen (i.e. the subballast material was outside the cellular mattress); but the vertical deformation of subballast at the centre of the geocell mattress was much less than unreinforced subballast, indicating the effectiveness of geocell in reducing the stress to the lower soil layer.

Figs. 6(a \& b) show a comparison between the vertical settlement $\left(S_{V}\right)$ of unreinforced and geocell-reinforced subballast obtained from the FEM model, and that measured in the laboratory at different confining pressures $\left(\sigma_{3}^{\prime}=10-20 \mathrm{kPa}\right)$ and frequency of $f=10 \mathrm{~Hz}$. The vertical deformation obtained from the FEM simulation agrees with the experimental data. Most of deformation in unreinforced subballast occurs in the early stage of loading $(N \leq$ 5,000 cycles). This is because immediate settlement takes place during the initial number of cycles. The experimental and numerical results both confirm that the rate of settlement 
diminishes to a controlled steady state after $N \geq 5,000$ cycles. The numerical and experimental results also confirm that the magnitude of $S_{V}$ decreases by increasing $\sigma_{3}^{\prime}$. Fig.

292 6(a) shows that the axial settlement decreases from $S_{V}=17.5 \mathrm{~mm}$ to $S_{V}=6 \mathrm{~mm}$ by increasing the confining pressure from $\sigma_{3}^{\prime}=10 \mathrm{kPa}$ to $\sigma_{3}^{\prime}=20 \mathrm{kPa}$.

295 At a given confining pressure, the magnitude of $S_{V}$ in the reinforced assembly is much less than that of the unreinforced specimen [Fig. 6(b)]. In fact the experimental and numerical results confirm that the geocell has the highest impact on the specimens at lower confining pressures $\left(\sigma_{3}^{\prime} \leq 15 \mathrm{kPa}\right)$. They also verify that at a given load cycle the magnitude of $S_{V}$ decreases by increasing $\sigma_{3}^{\prime}$ (i.e. at the load cycle $N=10,000$, vertical settlement in the reinforced specimen was about $S_{V}=12.5 \mathrm{~mm}$ and it was $6.0 \mathrm{~mm}$ when $\sigma_{3}^{\prime}=10 \mathrm{kPa}$ and 20 $\mathrm{kPa}$, respectively). A marginal reduction in axial settlement is observed in the reinforced specimen by increasing confining pressure of about $\sigma_{3}^{\prime} \geq 20 \mathrm{kPa}$, where similar performance is observed in the unreinforced and reinforced specimens.

\subsection{Lateral spreading}

Fig. 7 shows the variations of lateral spreading $\left(S_{L}\right)$ with the depth of unreinforced subballast under a confining pressure of $\sigma_{3}^{\prime}=10 \mathrm{kPa}$ and a frequency of $f=10 \mathrm{~Hz}$ at different load cycles, that was obtained from the FE model and measured experimentally. At a given number of load cycles the lateral spreading of subballast increases with depth until it reaches a maximum displacement at a depth of about $h=250-300 \mathrm{~mm}$, and then $S_{L}$ decreases at a

311 lower depth $(h<250 \mathrm{~mm})$. A similar trend also occurred at other load cycles, where the 312 subballast spread slightly at the base of the assembly $(h=450 \mathrm{~mm})$. 
314 The beneficial effect of geocell can be highlighted in terms of minimizing lateral spreading

$315 S_{L}$, as shown in Figs. 8(a \& b). Almost all lateral displacement within the geocell has been

316

317

Fig. 8(b) presents the variations of lateral spreading $\left(S_{L}\right)$ with the depth of reinforced subballast under a confining pressure of $\sigma_{3}^{\prime}=10 \mathrm{kPa}$ at different numbers of load cycles. As expected, the magnitude of lateral spreading increases as the number of cycles $(N)$ increases and lateral spreading beneath the geocell-reinforced layer also increases. The value of $S_{L}$ reaches a maximum at a depth of approximately subballast height of $h=200-250 \mathrm{~mm}$, where it is much lower than the unreinforced specimen. This figure shows that at a given number of load cycles there is almost no lateral spreading of subballast within the geocell due to the additional confinement provided by the geocell.

The beneficial effects of the geocell mattress can best be interpreted by comparing the lateral displacement $\left(S_{L}\right)$ of unreinforced and reinforced subballast obtained from experimental and numerical modelling under different confining pressures $\left(\sigma_{3}^{\prime}=10-20 \mathrm{kPa}\right)$ at $f=10 \mathrm{~Hz}$ [Figs. 9(a \& b)]. A good agreement is observed between the laboratory and numerical results. Under a low confining pressure (i.e. $\sigma_{3}^{\prime} \leq 15 \mathrm{kPa}$ ), unreinforced subballast experiences considerable lateral deformation, while the magnitude of $S_{L}$ decreases with an increase in $\sigma_{3}^{\prime}$ [Fig. 9(a)]. In general, reinforced assembly exhibits less lateral displacement than the unreinforced assembly at a given confining pressure and load cycle, while the specimen reinforced with the geocell performs better under a low confining pressure (i.e. $\sigma_{3}^{\prime} \leq 15 \mathrm{kPa}$ ). 
Marginal improvement is observed in the reinforced specimen at a higher confining pressure of $\sigma_{3}^{\prime} \geq 20 \mathrm{kPa}$ [Fig. 9(b)].

341 Based on the results obtained from the tests and numerical modelling, settlement $\left(R_{s}\right)$ and lateral $\left(R_{L}\right)$ deformation reduction factors for different confining pressures were introduced and provided in Table 3. The beneficial effect of the geocell to reduce the subballast

344 deformation is clearly reflected by $R_{S}$ and $R_{L}$. Indeed the maximum beneficial effect of geocell reinforcement can be seen at a low confining pressure which is often observed in the field. At a low confining pressure $\left(\sigma_{3}^{\prime} \leq 10 \mathrm{kPa}\right)$, geocell can reduce the deformation of subballast (approximately 25\% and 35\% reduction for settlement and lateral displacement, respectively), and this value significantly decreases as the confining pressure increases (approximately only $10 \%$ and $16 \%$ reduction for settlement and lateral displacement, respectively, for $\left.\sigma_{3}^{\prime}=30 \mathrm{kPa}\right)$.

351

\subsection{Distribution of stress in the subballast}

The deviator stress contours $(q)$ of subballast reinforced with geocell under a confining pressure of $\sigma_{3}^{\prime}=10 \mathrm{kPa}$ and a frequency of $f=10 \mathrm{~Hz}$ during loading and unloading process ( $\sigma_{\max }=166 \mathrm{kPa}$ and $\sigma_{\min }=41 \mathrm{kPa}$ ) at a load cycle of $N=10,000$ are presented in Figs. 10 (a

\& b). During the loading stage stress concentration occurs inside the geocell [i.e. point $\mathrm{C}$ in Fig. 10(a)], because the subballast is confined inside these pockets and prevented from displacement. The deviator stress is much less in the middle of the geocell mattress (point Din Figure 10a) compared to the edges. Also Fig. 10(a) highlights the impact of the testing condition (i.e. plane strain) during the simulation. Under loading, the granular material can spread laterally in the transverse direction. However, in the direction parallel to the track 
362 (longitudinal direction), (points A \& B), the lateral displacement is prevented $\left(\varepsilon_{2}=0\right)$, with a 363 corresponding intermediate stress of $\sigma_{2}^{\prime}=120-140 \mathrm{kPa}$, which is markedly greater than $\sigma_{3}^{\prime}$

$364(25-45 \mathrm{kPa})$. This can be attributed to the impact of intermediate stress $\left(\sigma_{2}^{\prime}\right)$ and boundary 365 condition in plane strain condition $\left(\varepsilon_{2}=0\right)$. However, for the remainder of the specimen, the geocell mattress successfully captures the intensity of applied cyclic loading and less stress was transferred to the lower layer of soil, which again confirms the effectiveness of a geocell mattress, when it is placed beneath the footing.

369

One of the benefits of numerical modelling is investigating the effect of intermediate stress ( $\sigma_{2}^{\prime}$ ). The numerical results show that the magnitude of stress that developed in the direction of $\sigma_{2}^{\prime}$ [side EFGH in Fig. 10(b)] is much higher than $\sigma_{3}^{\prime}$ (about $\sigma_{2}^{\prime}=60-80 \mathrm{kPa}$ ). This can be justified because of the boundary condition which has led to the accumulation of stress in this direction. With conventional design criteria, the degree of intermediate stress is usually assumed to be equal to the minor principal stress $\left(\sigma_{2}^{\prime}=\sigma_{3}^{\prime}\right)$, but this simulation shows there is a remarkable dissimilarity between $\sigma_{3}^{\prime}$ and $\sigma_{2}^{\prime}$ when the experiment is carried out in plane strain condition, which is similar to field conditions.

\subsection{Distribution of Stress in the geocell mattress}

The tensile strength of geocell is an important parameter, affecting the performance of geocell-reinforced subballast, where it is usually assumed to be constant in conventional design practices (Indraratna et al. 2015; Leshchinsky and Ling 2013b). However, the results obtained from numerical modelling indicate that during cyclic loading, the mobilized tensile stress of geocell changes considerably at the loading and unloading stages, where there are maximum and minimum tensile stresses at the loading and unloading stages respectively 
[Figs. 11(a \&b)]. Figure 11(a) shows that during the loading stage, maximum tensile stress is mobilized in the geocell due to preventing the infill subballast from excessive lateral spreading. The middle of the geocell strip (e.g. point A) in the direction parallel to the minor principal stress $\left(\sigma_{3}^{\prime}\right)$ has experienced the highest degree of mobilized tensile stress. Figure 11(a) also shows that minimum tensile stress occurs in the direction parallel to the intermediate principal stress $\sigma_{2}^{\prime}$ (e.g. point C), where the geocell mattress is not allowed to move in this direction (i.e. parallel to the sleepers). This study verifies that stress over the geocell strip is distributed non-uniformly across the geocell where the mobilized tensile stresses in the middle pocket (Point B) are considerably less than those in the surrounding pockets. Compared to the loading stage, the mobilized tensile stress in the geocell during the unloading stage is also non-uniform, although the observed magnitude is much lower, as shown in Fig. 11(b). This study shows that the improved performance of geocell-reinforced subballast is controlled mostly by the mobilized tensile stress of the reinforcement where the maximum mobilized tensile stress is much less than the ultimate tensile strength of the geocell.

401

402 The influence of confining pressure on the mobilized tensile stress in the geocell was also 403 investigated by comparing the mobilized tensile stress at a corresponding confining pressure of $\sigma_{3}^{\prime}=5-30 \mathrm{kPa}$. Fig. 12 shows that the mobilized tensile stress reaches its highest magnitude at the lowest confining pressure $\left(\sigma_{3}^{\prime}=5 \mathrm{kPa}\right)$ and decreases significantly as $\sigma_{3}^{\prime}$ 406 increases (i.e. geocell mobilized a tensile stress of around 2.5 MPa and 0.5 MPa under a confining pressure of $\sigma_{3}^{\prime}=5 \mathrm{kPa}$ and $30 \mathrm{kPa}$, respectively). This observation confirms the fact 408 that the beneficial effect of geocell is mobilized under the low confining pressure often seen 409 in actual track conditions. 


\section{Practical implications}

412 The influence of subballast stiffness on the behaviour of geocell-reinforced subballast was

413 investigated by comparing the lateral spreading and mobilized tensile strength of geocell. Fig.

414 13(a) shows the tensile stress mobilized in the geocell $\left(E_{\text {geocell }}=0.3 \mathrm{GPa}\right)$ and lateral

415 spreading $\left(S_{L}\right)$ in a reinforced specimen with subballast of different compressive strengths (4

$416 \mathrm{MPa} \leq E_{\text {subballast }} \leq 40 \mathrm{MPa}$ ) during the loading stage. It is observed that the maximum

417 mobilized tensile stress occurs on the subballast with the lowest degree of stiffness ( $E_{\text {subballast }}$

$418=4 \mathrm{MPa}$ ). This is because the infill soil becomes stiffer by transferring the cyclic load as

419 hoop stress (mobilizes tensile stress) to the geocell, where lowering the stiffness of the infill

420 materials enables a greater hoop stress in the geocell. As expected, lateral spreading

421 decreases significantly as the stiffness of the subballast is increased.

422

423 The effect of the subballast strength and stiffness of geocell can also be evaluated by 424 comparing the reduction factor $\left(R_{L}\right)$ of lateral spreading in reinforced subballast. Figure 13(b)

425 shows the magnitude of $R_{L}$ for geocell with different stiffness and subballast strength under $426 \sigma_{3}^{\prime}=30 \mathrm{kPa}$ and at $N=10,000$ cycles. As shown by Fig. 13(b), for different subballast

427 stiffness ( $E_{\text {subballast }}$ ), the value of $R_{L}$ was varied between $32 \leq R_{L} \leq 20 \%$. The maximum value 428 of $R_{L}>30 \%$ occurred at $E_{\text {subballast }} \leq 10 \mathrm{MPa}$. In addition, for the soil with relatively higher 429 strength, $R_{L}=20 \%$ could still be achieved.

430

431 The reinforced specimen exhibited a wider range of $R_{L}$ that corresponded to variations in the 432 stiffness of geocell ( $\left.E_{\text {geocell }}\right)$, where the value of $R_{L}$ varied from $30 \%$ up to about $75 \%$, 433 depending on the stiffness of geocell used. These results indicate the effectiveness of cellular 434 confinement, where a larger $R_{L}$ occurs in the geocell with a higher stiffness. One practical 435 implication of this study is that the rail industry can continue to use subballast of relatively 
436 low compressive strength that can be improved by geocell, while still ensuring an acceptable 437 performance at a lower manufacturing cost. Moreover in the absence of high-strength 438 granular materials, the numerical simulations presented in this study can be used in the 439 preliminary design of track substructure where a wide range of granular materials and geocell 440 mattresses with different strengths and stiffness can be considered.

\section{Parametric study}

\subsection{Strength of the Subballast}

444 Since the supply of aggregates with high strength is limited, the use of granular materials with low strength in combination with the geosynthetic reinforcement is inevitable. Perhaps the greatest advantage of numerical analysing is that it provides an insight into the behaviour of specimens with different properties. By taking advantage of this, a model of geocellreinforced subballast with a wide range of stiffnesses (4 MPa $\leq E_{\text {subballast }} \leq 40 \mathrm{MPa}$ ) was simulated to evaluate the performance of geocell on the subballast having varying stiffnesses. A range of stiffnesses ( $4 \mathrm{MPa} \leq E_{\text {subballast }} \leq 40 \mathrm{MPa}$ ) was selected to represent soft soils to the very stiff aggregates commonly used as subballast materials. The results showed that an improvement in the behaviour of reinforced subballast decreased as the stiffness of subballast increased, which is in agreement with the previous study (Biswas et al. 2013). Fig. 14(a) shows that the lateral displacement of unreinforced subballast decreases as the subballast stiffness increases, while a specimen with very low strength experiences significant lateral displacement (i.e. $S_{L}=7.50 \mathrm{~mm}$ for $E_{\text {subballast }}=4 \mathrm{MPa}$ compared to $S_{L}=1.50 \mathrm{~mm}$ for $E_{\text {subballast }}$ $=40 \mathrm{MPa}$ ). This figure also shows that regardless of the strength of the subballast, maximum lateral spreading occurs at the depth of $h=250-300 \mathrm{~mm}$. Nevertheless, in the reinforced specimen, the inclusion of geocell decreased lateral spreading markedly when the subballast

460 had relatively low stiffness (i.e. $E_{\text {subballast }} \leq 10 \mathrm{MPa}$ ) [Fig. 14(b)]. The presence of the geocell 
mattress makes compaction to high levels of Relative Density (> 95\%) quite difficult, and therefore the current material with a bulk unit weight of $20.5 \mathrm{kN} / \mathrm{m}^{3}$ (approx. dry unit weight of $18.5 \mathrm{kN} / \mathrm{m}^{3}$, optimum moisture content $=11 \%$ ) cannot be considered as a highly dense subballast, but its dilation angle of $9^{\circ}$ (Table 2) still provides sufficient dilation to induce geocell hoop stress and the associated confining pressure. Marginal improvement was observed in the reinforced subballast compared to the unreinforced ballast at a higher modulus (30 MPa $\left.\leq E_{\text {subballast }}\right)$.

468

\subsection{Stiffness of Geocell}

470

The variety of polymeric material available, such as high-density polyethylene (HDPE) or novel polymeric alloy (NPA), made it necessary to investigate the influence of geocell stiffness on the performance of a reinforced subballast assembly. This was investigated by simulating geocell with a range of stiffness that varied from $0.3 \mathrm{GPa}$ to $5 \mathrm{GPa}$ to represent a variety of materials including HDPE, NPA, and structural steel. The lateral spreading of subballast under geocell with varying stiffness is presented in Fig. 15. As geocell stiffness increases the lateral displacement of subballast decreases in every case, while unreinforced subballast assembly exhibits the highest lateral displacement. The degree of lateral spreading of soil beneath the reinforced layer is reduced further by increasing the stiffness of geocell, indicating the effectiveness of the geocell on the lower soil layer. This figure also shows that geocell with a relatively low stiffness $E_{\text {geocell }}=0.3 \mathrm{GPa}$ performs very well compared to the geocell with a higher stiffness.

482

483

\section{Model validation}

484 By using the proposed analytical model (Indraratna et al. 2015), the model results compared 485 well with different sets of experimental data reported elsewhere (Leshchinsky and Ling 
2013a). The model was validated numerically (Fig. 16) to demonstrate that the current FE

487

488

489

490

491

492

493

494

495

496

497

498

499

500

501

502

503

504

505

506

507

508

509

510

model is a reasonable representation of an actual specimen of subballast reinforced with geocell, where the settlements and lateral displacements obtained from the model were compared with those measured experimentally. A model test with a truncated square pyramid with dimensions of $1524 \mathrm{~mm} \times 1524 \mathrm{~mm} \times 546 \mathrm{~mm}$ was simulated. For the purpose of validation purpose, a hexagonal shaped geocell mattress with a single layer $200 \mathrm{~mm}$ thick was developed. Cyclic loading amplitudes of $35 \mathrm{kPa} \leq q \leq 175 \mathrm{kPa}$ and $70 \mathrm{kPa} \leq q \leq 350 \mathrm{kPa}$ were used for the unreinforced and reinforced models, respectively. The cyclic load was applied on the top surface of the model via a rigid plate (plate size: $356 \mathrm{~mm}$ long $\times 356 \mathrm{~mm}$ width $\times 25$ mm thick) under $N=50,000$ cycles. A FE model with 12661 elements (C3D8R) and 21038 nodes was used for the analysis. An elasto-plastic material with non-associative behaviour was used to model the subballast, where the internal friction angle and dilatancy angle of granular material were chosen as 45 and 15 degrees, respectively. The base of the model was restricted from any displacement in order to model a concrete foundation as conducted in the laboratory; but each side was free to move to simulate field conditions. The model was then validated by the experimental and numerical data presented by Leshchinsky and Ling (2013a).

Figs. 17(a, b \& c) present comparisons of the predicted and measured vertical and lateral displacements of unreinforced and geocell-reinforced granular material, where a reasonably good agreement is found between the FEM predictions and the experimental results. The unreinforced model shows a vertical displacement of about $S_{V}=120 \mathrm{~mm}$, while only around $S_{V}=60 \mathrm{~mm}$ was predicted for the reinforced specimen. Compared to the model prediction presented by Leshchinsky and Ling (2013a), the current model provides better predictions, where most of vertical settlements occur within a range of $N=10,000$ load cycles [Fig. 
511 17(a)]. This figure also shows that the current FE analysis accurately captures the decreasing

512 rate of settlement as the number of load cycles is increased. By using a hexagonal shaped

513 geocell mattress that is similar to the actual shape used in the laboratory, the model is able to

514 capture more realistic mobilized tensile stress in the geocell strips.

515

516 Lateral displacements at the top and bottom of the model test are captured in the simulation 517 and compared with the published data, as shown in Figs. 17(b \& c). In general, the current FE

518 simulations match well with the experimental data, apart from the initial modulus predicted

519 for the reinforced models that is slightly greater than that for the models tested by 520 Leshchinsky and Ling (2013a). This can be attributed to differences in boundary conditions

521 between the FEM simulation and laboratory observations as well as the particle degradation

522 not considered in the current analysis. Although there are some disparities between the FEM

523 simulations and laboratory data, the proposed FEM model was able to model the advantages

524 attained from using geocell reinforcement, including lower deformation and greater strength

525 and stiffness.

526

527 8. Conclusion

528 The behaviour of subballast reinforced with geocell subjected to cyclic loading was 529 investigated using a series of large-scale prismoidal triaxial apparatus and numerical 530 modelling. The tests and numerical simulations were carried out to mimic the actual track

531 conditions. The model was compared with the experimental data and a reasonably good agreement was achieved. The numerical results were also validated by the published data.

533 The proposed FEM model can be effectively used to predict the performance of subballast

534 reinforced with a geocell mattress. A parametric study was also conducted to investigate the 
effects of subballast and geocell stiffness on the tensile strength mobilized in geocell mattress. The following conclusions can be drawn from this study:

1) The numerical results agree well with the experimental results, highlighting the effectiveness of 'mobilised additional confinement' under cyclic loading, attributed to the inclusion of geocell, whose hoop stress related confining pressure increases with the number of cycles. The test results indicate that the current three-dimensional FE modelling can successfully simulate vertical and lateral deformation of geocellreinforced subballast under cyclic loading at varying confining pressure over time. At a given confining pressure, deformation in the reinforced assembly was considerably less than that in the unreinforced subballast. The numerical and experimental results also confirmed that at a given load cycle the deformation decreased as the confining pressure increased. The observed benefit of geocell was maximum at the lowest confining pressure; after which it decreased as the confining pressure increased and became marginal when the confining pressure was $30 \mathrm{kPa}$.

2) Unlike the conventional design practices which consider a uniform distribution of stress over the geocell, this study epitomized that the mobilized tensile stress was distributed non-uniformly across the geocell, where the maximum mobilized tensile stress occurred in the direction parallel to the intermediate principal stress during the loading stage. Also it was confirmed that under cyclic loading, the tensile stress varied during loading and unloading cycles, and the ultimate tensile stress of a geocell mattress was never reached during the loading period of this study, i.e. after 10000 cycles.

3) The cellular confinement induced by the geocell mattress was effective in reducing the lateral spreading of the infilled material even when the granular mass confined within the geocells was not of good quality rockfill with very apparently high friction 
angles (e.g. highly angular quarried aggregates with internal friction angles often exceeding 50 degrees). This implies that marginal materials can be used as subballast when improved by the use of geocells, and this is clearly beneficial in railway practice where high quality aggregates may not be available locally.

4) A parametric study was carried out to evaluate the effect of subballast and geocell stiffness on performance of a composite system. It was found that in reinforced specimen lateral displacement was reduced further when the stiffness of subballast had lower stiffness (i.e. $E_{\text {subballast }} \leq 10 \mathrm{MPa}$ ), indicating that subballast with low compressive strength could perform well with a geocell inclusion. Furthermore, an increase in the geocell stiffness reduced the deformation in the subballast, while a stiffer geocell exhibited less lateral displacement. This study would encourage practising engineers to use a subballast of relatively low compressive strength improved with geocell, while still ensuring an acceptable performance at a lower manufacturing cost.

5) Maximum vertical displacement $\left(S_{V}\right)$ occurred directly under the footing where the cyclic loading was at its maximum. The intensity of $S_{V}$ decreased at a lower depth. The numerical results also showed that maximum lateral displacements in the unreinforced specimen occurred at a depth of about $h=250-300 \mathrm{~mm}$, and then $S_{L}$ decreases at a lower depth $(h<250 \mathrm{~mm})$. As a result, utilizing geocell in the subballast layer will

\section{Acknowledgments}

582 The authors to acknowledge the financial support received from the Research Centre for

583 Geomechanics and Railway Engineering (GRE) and the Australian Research Council (ARC). 
584 The authors are grateful for Alan Grant, Laboratory Manager and Ritchie McLean, Technical

585 Officer at GRE for their assistance during laboratory testing.

586

587

588 List of symbols

$$
\begin{aligned}
& b=\text { distance between two adjacent sleepers(mm) } \\
& C_{c}=\text { coefficient of curvature } \\
& C_{r}=\text { apparent cohesion }(\mathrm{kPa}) \\
& C_{u}=\text { uniformity coefficient } \\
& D_{10}=\text { diameter for } 10 \% \text { fine by weight }(\mathrm{mm}) \\
& D_{20}=\text { diameter for } 20 \% \text { fine by weight }(\mathrm{mm}) \\
& D_{30}=\text { diameter for } 30 \% \text { fine by weight }(\mathrm{mm}) \\
& D_{50}=\text { average particle size }(\mathrm{mm}) \\
& D_{60}=\text { diameter for } 60 \% \text { fine by weight }(\mathrm{mm}) \\
& D_{\max }=\text { maximum particle size }(\mathrm{mm}) \\
& D_{\min }=\text { minimum particle size }(\mathrm{mm}) \\
& D_{R}=\text { relative density (\%) } \\
& D_{r}=\text { depth of reinforcement (mm) } \\
& E=\text { elastic modulus (MPa) } \\
& E_{\text {subballast }}=\text { subballast strength }(\mathrm{MPa}) \\
& E_{\text {geocell }}=\text { geocell stiffness }(\mathrm{GPa}) \\
& f=\text { frequency }(\mathrm{Hz}) \\
& h=\text { specimen height }(\mathrm{mm}) \\
& \delta=\text { interface coefficient } \\
& k_{\sigma}=\text { normalized confinement ratio } \\
& R_{L}=\text { lateral spreading reduction factor (\%) } \\
& R_{s}=\text { settlement reduction factor (\%) } \\
& L=\text { total length of sleeper }(\mathrm{mm}) \\
& l_{e}=\text { effective length of sleeper supporting the load (mm) } \\
& M=\text { geocell modulus }(\mathrm{kN} / \mathrm{m}) \\
& M_{m}=\text { mobilized geocell modulus }(\mathrm{kN} / \mathrm{m}) \\
& N=\text { number of cycles }
\end{aligned}
$$




$$
\begin{aligned}
q_{\text {max }} & =\text { maximum amplitude }(\mathrm{kPa}) \\
q_{\text {mean }} & =\text { mean load }(\mathrm{kN}) \\
q_{\text {min }} & =\text { minimum amplitude }(\mathrm{kPa}) \\
S_{L} & =\text { lateral spreading }(\mathrm{mm}) \\
S_{V} & =\text { vertical deformation }(\mathrm{mm}) \\
\gamma_{d} & =\text { dry unit weight of the soil }\left(\mathrm{kN} / \mathrm{m}^{3}\right) \\
\delta & =\text { interface friction angle of subballast-geosynthetic }(\text { degree }) \\
\varepsilon_{2} & =\text { lateral strain parallel to intermediate principal stress }(\%) \\
\varepsilon_{3} & =\text { lateral strains parallel to minor principal stress }(\%) \\
\varepsilon_{v} & =\text { volumetric strain }(\%) \\
\varepsilon_{v}^{p} & =\text { plastic volumetric strain }(\%) \\
v_{g} & =\text { Poisson's ratio of geocell } \\
\sigma_{1} & =\text { major principal stress }(\mathrm{kPa}) \\
\sigma_{2}^{\prime} & =\text { intermediate principal stress }(\mathrm{kPa}) \\
\sigma_{3}^{\prime} & =\text { minor principal stress }(\mathrm{kPa}) \\
\Delta \sigma_{3}^{\prime} & =\text { additional confining pressure }(\mathrm{kPa}) \\
\sigma_{c y c} & =\text { cyclic deviator stress }(\mathrm{kPa}) \\
\sigma_{\text {max }} & =\text { maximum stress }(\mathrm{kPa}) \\
\sigma_{\text {mean }} & =\text { mean stress }(\mathrm{kPa}) \\
\sigma_{\text {min }} & =\text { minimum stress }(\mathrm{kPa}) \\
\phi & =\text { internal friction angle of unreinforced soil (degree) } \\
\psi & \text { dilation angle }(\text { degrees }) \\
&
\end{aligned}
$$




\section{Appendix: Calculation of applied stress on the subballast}

592 For calculating the maximum contact pressure on the top of subballast surface, a nominal

593 axle load of $294 \mathrm{kN}$ (30 tons) was assumed, and this is equivalent to a vertical pressure of

$594147 \mathrm{kN}$. The design wheel load can then be calculated using (Li and Selig 1998):

595

$$
P_{d}=\phi \cdot P_{s}
$$

where, $P_{s}$ is the static wheel load $(\mathrm{kN}), P_{d}$ is the design wheel load $(\mathrm{kN})$, and $\phi$ is the impact

597

598

599

600

601

602 as

By substituting train speed $(v)$ as $73 \mathrm{~km} / \mathrm{h}$ (corresponding to $f=10 \mathrm{~Hz}$ ), and wheel diameter $D_{w}$ as $0.97 \mathrm{~m}$, the design wheel load $P_{d}$ was determined to be about 200-208 kN. Considering $50 \%$ of pressure transmitted to the adjacent sleepers (varies from $50-60 \%$ as shown by Atalar et al., 2001), the rail seat load $\left(q_{r}\right)$ can be obtained about 100-104 kN. Assuming a uniform distribution of stress, the contact pressure at the ballast-sleeper interface $\left(P_{a}\right)$ can then be computed$$
\text { and }
$$$$
\text { Tew }
$$$$
\text { 1991): }
$$

where, $F_{2}$ is a factor depending on track maintenance and sleeper type $\left(F_{2}=1\right), B$ is the width of sleeper $(B=260 \mathrm{~mm}), l$ is the total length of sleeper $(l=2400 \mathrm{~mm})$ and $L$ is the effective length of sleeper. By assuming the effective length of sleeper as one third of the total sleeper length (Jeffs and Tew 1991), Eq [3] becomes:

$$
P_{a}=\left(\frac{3 q_{r}}{B \times l}\right) F_{2}
$$

611 According to Japanese Track Standards, considering $L$ as $2 d$, where, $d$ is distance between the

612 rail head center and edge of the sleeper $(d=500 \mathrm{~mm})$, following equation can be used to 613 obtain $P_{a}$ (Atalar et al. 2001): 


$$
P_{a}=\frac{q_{r}}{2 d B} F_{2}
$$

616 Considering Eqns. [3], [4] and [5], a maximum of $P_{a}$ (i.e. $P_{a}=492 \mathrm{kPa}$ ) was considered.

617 Considering the sleeper area $(L=800 \mathrm{~mm}, B=260 \mathrm{~mm})$ and a ballast depth of $300 \mathrm{~mm}$, the

618 stress on top of subballast can then be calculated of about 160-170 kPa using Boussinesq

619 elastic theory. A minimum amplitude $\left(\sigma_{\min }\right)$ of $41 \mathrm{kPa}$ was selected to represent in situ 620 unloaded track state.

621

622

623

624

625

626

627

628

629

630

631

632

633

634

635

636 


\section{REFERENCES}

638

639

640

641

642

643

644

645

646

647

648

649

650

651

652

653

654

655

656

657

658

659

660

ASTM. (2011). Standard test method for determining performance strength of geomembranes by the wide strip tensile method. D4885-01(2011), West Conshohocken, PA.

Atalar, C., Das, B. M., Shin, E. C., and Kim, D. H., 2001. Settlement of geogrid-reinforced railroad bed due to cyclic load. Proc., 15th Int. Conf. on Soil Mechanics and Geotechnical Engineering. Vol. 3, CRC Press, Boca Raton, FL, 2045-2048.

Bathurst, R. J. and Knight, M. A., 1998. Analysis of geocell reinforced-soil covers over large span conduits. Computers and Geotechnics. 22(3-4), 205-219.

Biabani, M. M. and Indraratna, B., 2015. An evaluation of the interface behaviour of rail subballast stabilised with geogrids and geomembranes. Geotext. Geomembr. 43(3), 240-249.

Biswas, A., Krishna, A. M., and Dash, S. K., 2013. Influence of subgrade strength on the performance of geocell-reinforced foundation systems. Geosynthetics Int. 20(6), 376388.

Bolton, M. D., 1986. The strength and dilatancy of sands. Géotechnique, 36(1), 65-78.

Chen, C., McDowell, G. R., and Thom, N. H., 2012. Discrete element modelling of cyclic loads of geogrid-reinforced ballast under confined and unconfined conditions. Geotextiles and Geomembranes. 35: 76-86.

Choudhury, J., 2009. Track reconditioning guidelines. TMC 403 engineering manual, RailCorp, Chippendale, NSW, Australia.

Ferellec, J.-F. and McDowell G. R., 2012. Modelling of ballast-geogrid interaction using the discrete-element method. Geosynthetics International. 19(6): 470-479.

Han, J., Pokharel, S. K., Yang, X., Manandhar, C., Leshchinsky, D., Halahmi, I., Parsons, R. L., 2011. Performance of Geocell-Reinforced RAP Bases over Weak Subgrade under 
661

662

663

664

665

666

667

668

669

670

671

672

673

674

675

676

677

678

679

680

681

682

683

684

685

Full-Scale Moving Wheel Loads. Journal of Materials in Civil Engineering. 23(11): 1525-1534.

Han, J., Yang, X. M., Leshchinsky, D. and Parsons, R. L., 2008. Behavior of geocellreinforced sand under a vertical load. Transportation Research Record. (2045): 95-101.

Hegde, A. M., and Sitharam, T. G., 2015. Three-dimensional numerical analysis of geocellreinforced soft clay beds by considering the actual geometry of geocell pockets. Canadian Geotechnical Journal 52(9): 1396-1407.

Hegde A. and Sitharam, T. G., 2013. Experimental and numerical studies on footings supported on geocell reinforced sand and clay beds. International Journal of Geotechnical Engineering. 7(4), 346-354.

Hegde, A. and Sitharam, T. G., 2014. 3-Dimensional numerical modelling of geocell reinforced sand beds. Geotext. Geomembr. 1-11.

Huang, J., Bhandari, A., Yang, X., 2011., 2011. Numerical modelling of geosyntheticreinforced earth structures and geosynthetic-soil interactions. Geotechnical engineering. 42(1): 42-55.

Indraratna, B., Salim, W. \& Rujikiatkamjorn, C. (2011). Advanced Rail Geotechnology Ballasted Track, CRC Press/Balkema.

Indraratna, B., Ngo, N. T., and Rujikiatkamjorn, C., 2011. Behavior of geogrid-reinforced ballast under various levels of fouling. Geotext. Geomembr. 29(3), 313-322.

Indraratna, B., Ngo, N. T., and Rujikiatkamjorn, C., 2013. Studying the deformation of coal fouled ballast stabilised with geogrid under cyclic load. Journal of Geotechnical and Geoenvironmental Engineering, ASCE. 139(8), 1275-1289.

Indraratna, B., Biabani, M. and Nimbalkar, S., 2015. Behavior of geocell-reinforced subballast subjected to cyclic loading in plane-strain condition. Journal of Geotechnical and Geoenvironmental Engineering. 141(1), 04014081-16 
686

687

688

689

690

691

692

693

694

695

696

697

698

699

700

701

702

703

704

705

706

707

708

Jeffs, T., and Tew, G. P., 1991. A review of track design procedures: Sleepers and ballast, Vol. 2, Railways of Australia BHP Research, Melbourne Laboratories, Melbourne, Australia.

Kwon, J., and Tutumluer, E., 2009. Geogrid base reinforcement with aggregate interlock and modelling of associated stiffness enhancement in mechanistic pavement analysis. Transportation Research Record 2116, Transportation Research Board, Washington, DC, 85-95.

Leshchinsky, B. and Ling, H., 2013a. Effects of geocell confinement on strength and deformation behavior of gravel. Journal of Geotechnical and Geoenvironmental Engineering. 139(2), 340-352.

Leshchinsky, B. and Ling, H. I., 2013b. Numerical modelling of behavior of railway ballasted structure with geocell confinement. Geotext. Geomembr. 36(0), 33-43.

Latha, G. M. and Rajagopal, K., 2007. Parametric finite element analyses of geocellsupported embankments. Canadian Geotechnical Journal. 44(8): 917.

Latha, G.M and Somwanshi, A., 2009. Effect of reinforcement form on the bearing capacity of square footings on sand. Geotext. Geomembr. 27(6), 409-422.

Li, D. and Selig, E.T. (1998). “Method for railroad track foundation design, I: Development.” J. of Geotechnical and Geoenvironmental Engineering, ASCE, 124(4), 316-322.

Ling, H., Leshchinsky, D., Wang, J. P., Mohri, Y. and Rosen, A., 2009. Seismic response of geocell retaining walls: Experimental studies. J. Geotech. Geoenviron. Eng., 135(4), $515-524$.

Lu, M. and McDowell, G. R., 2010. Discrete element modelling of railway ballast under monotonic and cyclic triaxial loading. Géotechnique 60(6): 459-467. 
Mehdipour, I., Ghazavi, M. and Moayed, R. Z., 2013. Numerical study on stability analysis of geocell reinforced slopes by considering the bending effect. Geotext. Geomembr. 37(0), 23-34.

Moghaddas Tafreshi, S.N., Khalaj, O., and Dawson, A. R., 2014. Repeated loading of soil containing granulated rubber and multiple geocell layers. Geotextiles and Geomembranes. 42: 25-38.

Ngo, N. T., Indraratna, B., and Rujikiatkamjorn, C., 2014. DEM simulation of the behaviour of geogrid stabilised ballast fouled with coal. Computers and Geotechnics. 55, 224-231.

Peters, J. F., Lade, P. V., and Bro, A., 1988. Shear band formation in triaxial and plane strain tests. Advanced triaxial testing of soil and rock, R. T. Donaghe, R. C. Chaney, and M. L. Silver, eds., ASTM, West Conshohocken, PA. 604-627.

Pokharel, S.K., Han, J., Leshchinsky, D., Parsons, R.L., Halahmi, I., 2010. Investigation of factors influencing behavior of single geocell reinforced bases under static loading. Geotext. Geomembr. 28 (6), 570-578.

Radampola, S. S., 2006. Evaluation and modelling performance of capping layer in rail track substructure. Ph.D. thesis, Central Queensland Univ., Rockhampton, QLD, Australia.

Radampola, S. S., Gurung, N., McSweeney, T., and Dhanasekar, M., 2008. Evaluation of the properties of railway capping layer soil. Comput. Geotech. 35(5), 719-728.

Saride, S., Puppala, A. J., Sitharam, T. G. and Gowrisetti, S., 2009. Numerical simulation of geocell-reinforced sand and clay. Proceedings of the Institution of Civil Engineers. Ground improvement. 162(4), 185-198.

Selig, E. T., and Waters, J. M., 1994. Track geotechnology and substructure management, Thomas Telford, London. 
Suiker, A. S. J., Selig, E. T., and Frenkel, R., 2005. Static and cyclic triaxial testing of ballast and subballast. J. Geotech. Geoenviron. Eng., 10.1061/(ASCE)10900241(2005)131:6(771), 771-782.

Tafreshi, S.N.Moghaddas, Dawson, A.R., 2012. A comparison of static and cyclic loading responses of foundations on geocell reinforced sand. Geotext. Geomembr. 32, 55-68.

Tennakoon, N. C., 2012. Geotechnical study of engineering behaviour of fouled ballast. PhD. thesis. University of Wollongong, Australia.

Tavakoli Mehrjardi, Gh, Tafreshi, S.N.Moghaddas, Dawson, A.R., 2012. Combined use of geocell reinforcement and rubber soil mixtures to improve performance of buried pipes. Geotext. Geomembr. 34, 116-130.

Wanatowski, D., Chu, J., and Lo, R. S. C., 2008. Strain-softening behaviour of sand in strain path testing under plane-strain conditions. Acta Geotech. 3(2), 99-114.

Wang, G. Y., Zhang, J. P. and Zhao, J. W., 2013. Numerical analysis of geocell protective slope stability, Trans Tech.

Yang, X., Han, J., Leshchinsky, D., and Parsons, R., 2013. A three-dimensional mechanisticempirical model for geocell-reinforced unpaved roads. Acta Geotechnica. 8(2): 201213.

Yang, X., Han, J., Parsons, R. L. and Leshchinsky, D., 2010. Three-dimensional numerical modelling of single geocell-reinforced sand. Frontiers of Architecture and Civil Engineering in China. 4(2), 233-240.

Yu, H. S., and Sloan, S. W., 1997. Finite element limit analysis of reinforced soils. Comput. Struct. 63(3), 567-577. 
757

758 Table 1. Summary of research outcomes of previous studies.

759 Table 2. Finite element properties of subballast and geocell used in current study.

760 Table 3. A summary of $R_{L}$ and $R_{S}$ obtained from the numerical results.

761

762

763

764

765

766

767

768

769

770

771

772

773

774

775

776

777

778

779

780

781 


\section{List of Figures}

783

Figure 1. Cubical triaxial used in this study.

784

Figure 2. Finite element idealisation of typical rail environment.

785

Figure 3. (a) Typical boundary condition for unit cell and (b) vertical settlement predicted by

FE model with different number of elements.

787

Figure 4. Schematic illustration of cyclic loading.

788

Figure 5. FEM predicted vertical settlements: (a) unreinforced; and (b) geocell-reinforced

789 subballast.

790

Figure 6. Vertical deformation of (a) unreinforced and (b) geocell- reinforced subballast against number of cycles $(N)$ : laboratory measurements vs. model predictions.

792 Figure 7. Variation of lateral displacements with depth of unreinforced subballast.

793

Figure 8. Typical lateral deformation profile of reinforced geocell-reinforced subballast (a)

794 predicted by FEM and (b) at different depth and number of cycles.

795

Figure 9. Lateral displacement of (a) unreinforced and (b) reinforced subballast again number of cycles $(N)$ : laboratory measurements vs. model predictions.

Figure 10. Stress distribution during (a) loading and (b) unloading of unit cell in a geocell798 reinforced subballast.

799

Figure 11. Tensile stress mobilized in geocell mattress (a) loading and (b) unloading stage

800 subjected to cyclic loading.

801 Figure 12. Mobilized tensile stress at the geocell in reinforced subballast at different 802 confining pressures $\sigma_{3}^{\prime}$.

803 Figure 13. (a) Mobilized tensile stress at the geocell in reinforced subballast with different

804 stiffness and (b) reduction factor of lateral spreading for geocell-reinforced subballast.

805 Figure 14. Lateral spreading of (a) unreinforced and (b) geocell-reinforced subballast at 806 different strengths. 
807 Figure 15. Comparison of lateral spreading of unreinforced and geocell-reinforced subballast

808 at different geocell stiffness.

809 Figure 16. Typical FEM mesh of geometry of model and geocell mattress used for validation.

810 Figure 17. Model prediction compared with experiment and numerical results of (a) vertical

811 and lateral deformation at (b) the top and (c) bottom of the embankment.

812

813

814

815

816

817

818

819

820

821

822

823

824

825

826

827

828 
Table 1. Summary of research outcomes of previous studies.

\begin{tabular}{|c|c|c|c|c|c|c|}
\hline $\begin{array}{l}\text { Material } \\
\text { type }\end{array}$ & $\begin{array}{l}\text { Reinforcement } \\
\text { type }\end{array}$ & $\begin{array}{l}\text { Test specimen } \\
\text { scale }\end{array}$ & $\begin{array}{l}\text { Research } \\
\text { Methodology }\end{array}$ & Salient research outcomes & Limitations & Reference \\
\hline $\begin{array}{l}\text { Sand and } \\
\text { clay }\end{array}$ & Geocell & $\begin{array}{l}900 \times 900 \times 600 \\
\mathrm{~L} \times \mathrm{W} \times \mathrm{H}(\mathrm{mm})\end{array}$ & $\begin{array}{l}\text { Numerical } \\
\text { simulation (FLAC } \\
\text { 3D). }\end{array}$ & $\begin{array}{l}\text { 1) The geometry of the geocell } \\
\text { has a significant impact on the } \\
\text { load carrying capacity and } \\
\text { reducing the settlement of the } \\
\text { soil bed. } \\
\text { 2)The results revealed that } \\
\text { having three layers of planar } \\
\text { geogrids can be led to provide } \\
\text { optimum performance } \\
\text { improvement. }\end{array}$ & $\begin{array}{l}\text { Monotonic loading } \\
\text { only, hence cannot } \\
\text { interpret cyclic } \\
\text { loading behaviour. }\end{array}$ & $\begin{array}{l}\text { Saride et al. } \\
\text { (2009) }\end{array}$ \\
\hline $\begin{array}{l}\text { Clayey } \\
\text { sand and } \\
\text { soft clay }\end{array}$ & Geocell & $\begin{array}{l}50,000 \times 25,000 \\
\mathrm{~W} \times \mathrm{H}(\mathrm{mm}) \\
1000 \text { and } \\
2000 \mathrm{~mm} \\
\text { Geocell height }\end{array}$ & $\begin{array}{l}\text { Experimental and } \\
\text { numerical } \\
\text { investigation of } \\
\text { geocell supported } \\
\text { embankment } \\
\text { (GEOFEM) }\end{array}$ & $\begin{array}{l}\text { 1) Locally available material } \\
\text { can be used as infill material in } \\
\text { the absence of granular } \\
\text { material. } \\
\text { 2) Performance of the } \\
\text { reinforced embankment was } \\
\text { significantly improved by } \\
\text { increasing the aspect ratios } \\
\text { (optimum aspect ratio of } 1.0 \text { ) }\end{array}$ & $\begin{array}{l}\text { (1) Monotonic } \\
\text { loading } \\
\text { (2) Equivalent } \\
\text { composite model } \\
\text { (i.e soil and geocell } \\
\text { are integrated as one } \\
\text { material) }\end{array}$ & $\begin{array}{l}\text { Latha and } \\
\text { Rajagopal } \\
\text { (2007) }\end{array}$ \\
\hline Sand & $\begin{array}{l}\text { Geocell and } \\
\text { planar geogrid }\end{array}$ & $\begin{array}{l}900 \times 900 \times 600 \\
\mathrm{~L} \times \mathrm{W} \times \mathrm{H}(\mathrm{mm})\end{array}$ & $\begin{array}{l}\text { Experimental results } \\
\text { and numerical } \\
\text { investigation on the } \\
\text { bearing capacity of } \\
\text { square footings. }\end{array}$ & $\begin{array}{l}\text { 1) Geocell reinforcement was } \\
\text { found to be more effective than } \\
\text { other types of reinforcement. } \\
\text { 2) Numerical results confirmed } \\
\text { that by transferring the footing } \\
\text { load to deeper depth, stress and } \\
\text { strain underneath of the footing } \\
\text { will be markedly reduced. }\end{array}$ & $\begin{array}{l}\text { 1) Monotonic } \\
\text { loading } \\
\text { 2) The mobilised } \\
\text { stress over the } \\
\text { geocell was not } \\
\text { investigated. }\end{array}$ & $\begin{array}{l}\text { Latha and } \\
\text { Somwanshi, } \\
\text { (2009) }\end{array}$ \\
\hline
\end{tabular}




\begin{tabular}{|c|c|c|c|c|c|c|}
\hline Gravel & Geocell & $\begin{array}{l}1524 \times 610 \times 546 \\
\mathrm{~L} \times \mathrm{W} \times \mathrm{H}(\mathrm{mm})\end{array}$ & $\begin{array}{l}\text { Numerical } \\
\text { modelling of } \\
\text { behavior of railway } \\
\text { ballasted structure } \\
\text { with geocell } \\
\text { confinement }\end{array}$ & $\begin{array}{l}\text { 1) Providing geocell } \\
\text { reinforcement significantly } \\
\text { reduced vertical deformation, } \\
\text { particularly for materail with } \\
\text { lower quality. } \\
\text { 2) Geocell reinforcement } \\
\text { successfully arrested lateral } \\
\text { spreading along the slope of the } \\
\text { railroad substructure. }\end{array}$ & $\begin{array}{l}\text { 1) Confining } \\
\text { pressure assumed } \\
\text { constant during the } \\
\text { entire simulation. } \\
\text { 2) Diamond shaped } \\
\text { geocell pockets, } \\
\text { which are different } \\
\text { to actual geocell } \\
\text { configuration. }\end{array}$ & $\begin{array}{l}\text { Leshchinsky } \\
\text { and Ling } \\
\text { (2013) }\end{array}$ \\
\hline Gravel & Geogrid & $\begin{array}{l}300 \times 200 \times 400 \\
\mathrm{D} \times \mathrm{W} \times \mathrm{H}(\mathrm{mm})\end{array}$ & $\begin{array}{l}\text { Numerical } \\
\text { modelling } \\
\text { of ballast and } \\
\text { geogrid interaction } \\
\text { in pullout testing } \\
\text { (DEM). }\end{array}$ & $\begin{array}{l}\text { 1) It was found that pullout } \\
\text { force to be greater for the } \\
\text { clumps than for the spheres. } \\
\text { 2) Much more localised } \\
\text { deformation of the geogrid } \\
\text { observed as result of stronger } \\
\text { grid-particle interlock. }\end{array}$ & Geocells not used. & $\begin{array}{l}\text { Ferellec and } \\
\text { McDowell } \\
\text { (2012) }\end{array}$ \\
\hline
\end{tabular}




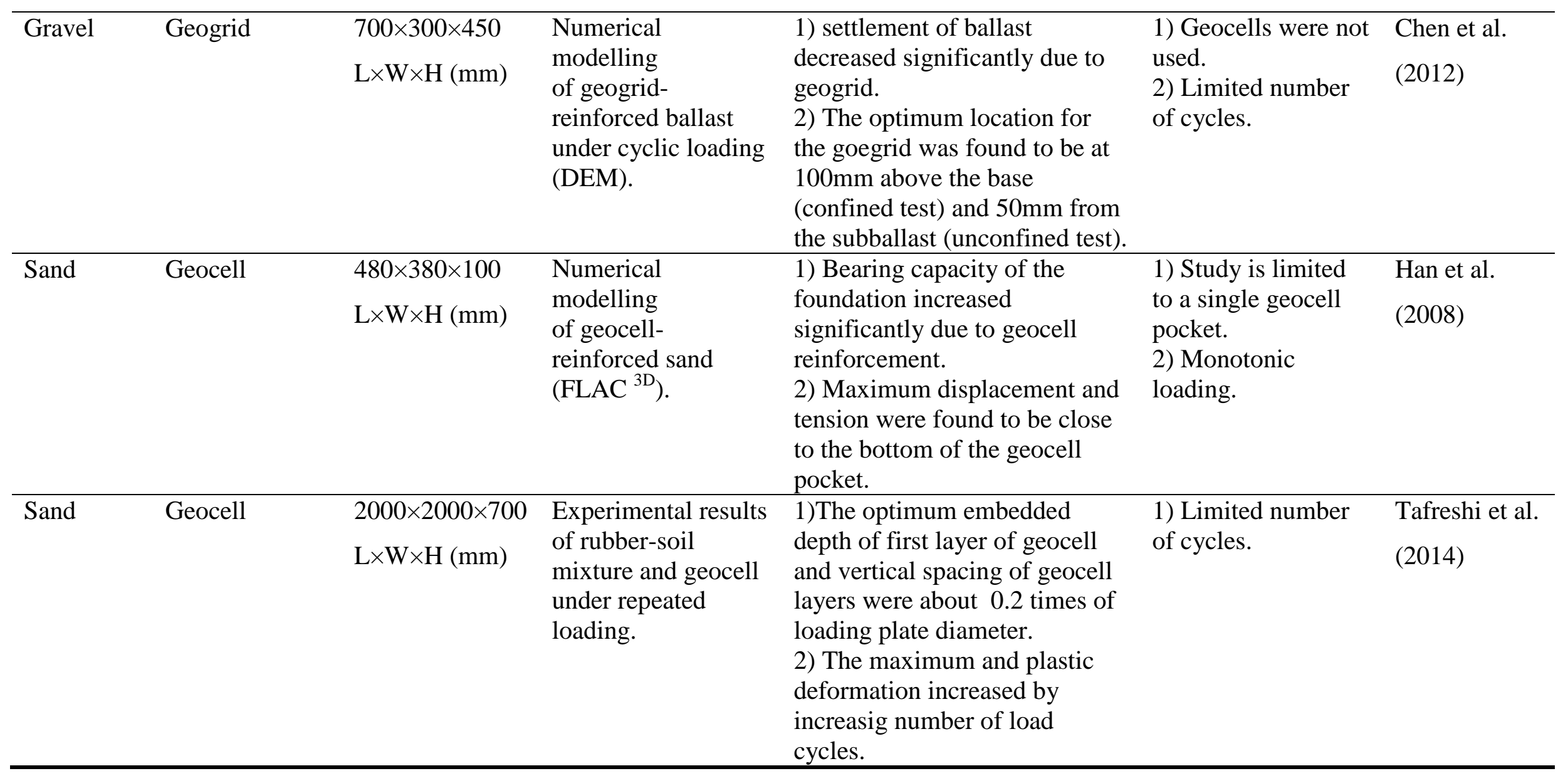


Table 2. Finite element properties of subballast and geocell used in current study.

\section{Subballast\& Subgrade}

\begin{tabular}{lllllll}
\hline Density & Poisson's & Elastic & Cohesion yield & Angle & of & Friction angle, \\
$\left(\mathrm{kg} / \mathrm{m}^{3}\right)$ & Ratio, $v$ & $\begin{array}{l}\text { modulus } \\
(\mathrm{MPa})\end{array}$ & stress $(\mathrm{kPa})$ & $\begin{array}{l}\text { dilation, } \\
\text { (degree) }\end{array}$ & $\phi$ (degree) \\
1,955 & 0.3 & $4-40$ & 2 & 9 & 39 \\
\hline
\end{tabular}

Geocell

\begin{tabular}{lll}
\hline Density $\left(\mathrm{kg} / \mathrm{m}^{3}\right)$ & Poisson’s Ratio, $v$ & Secant modulus (3\% strain), Egeocell
\end{tabular}

(GPa)
950
0.3
$0.3-5$

\section{Plate}

\begin{tabular}{lll}
\hline Density $\left(\mathrm{kg} / \mathrm{m}^{3}\right)$ & Poisson's Ratio, $v$ & Elastic modulus, $E_{\text {plate }}(\mathrm{GPa})$
\end{tabular}
2,000
0.3
500

\section{Subballast-geocell interface parameters}

\begin{tabular}{ll}
\hline$E_{\text {slip tolerance }}$ & Friction coefficient, $\delta$ \\
0.005 & $2 / 3 \phi$
\end{tabular}

831

832

833

834

835

836

837

838

839

840

841 
Table 3. A summary of $I_{L}$ and $I_{S}$ obtained from the numerical results.

\begin{tabular}{|c|c|c|c|c|c|c|}
\hline \multirow[t]{2}{*}{ Factor } & \multirow{2}{*}{$\begin{array}{c}f \\
(\mathrm{~Hz})\end{array}$} & \multicolumn{5}{|c|}{ Confining pressure, $\sigma_{3}^{\prime}(\mathrm{kPa})$} \\
\hline & & 5 & 10 & 15 & 20 & 30 \\
\hline \multicolumn{7}{|l|}{ Settlement reduction factor, $\mathrm{R}_{\mathrm{s}}(\%)$} \\
\hline$R_{S}=\frac{S_{V(\text { unreinf orced })}-S_{V(\text { reinf orced })}}{S_{V(\text { unreinf orced })}} \times 100$ & 10 & 31.25 & 25 & 14.55 & 12.67 & 10.5 \\
\hline \multicolumn{7}{|c|}{ Lateral displacement reduction factor, $\mathrm{R}_{\mathrm{L}}(\%)$} \\
\hline$R_{L}=\frac{S_{L(\text { unreinf orced })}-S_{L(\text { reinf orced })}}{S_{L(\text { unreinf orced })}} \times 100$ & 10 & 34.75 & 30.32 & 31.91 & 22.5 & 16.25 \\
\hline
\end{tabular}

843

844

845

846

847

848

849

850

851

852

853

854

855 

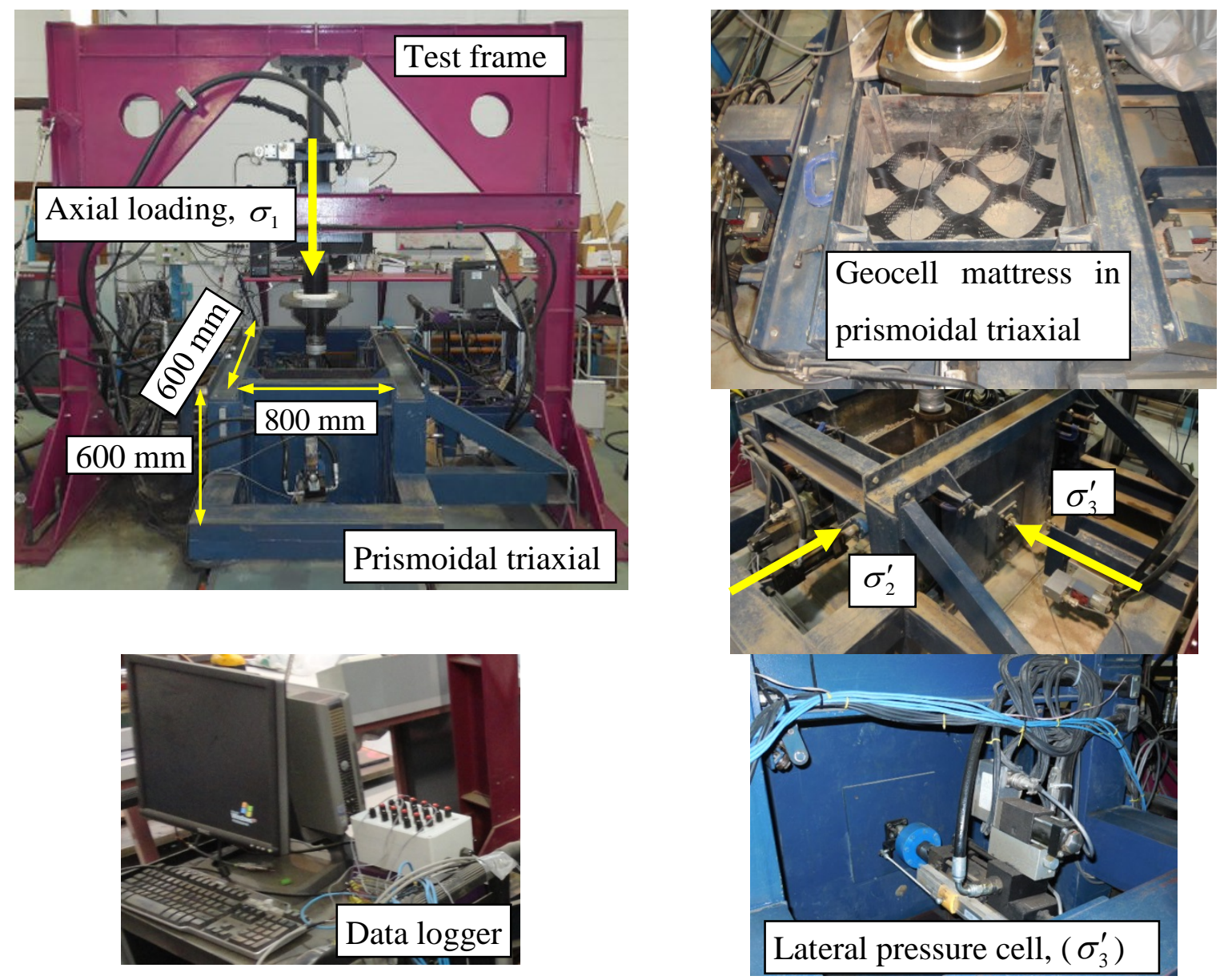

856

857

Figure 1. Cubical triaxial used in this study.

858

859

860

861 


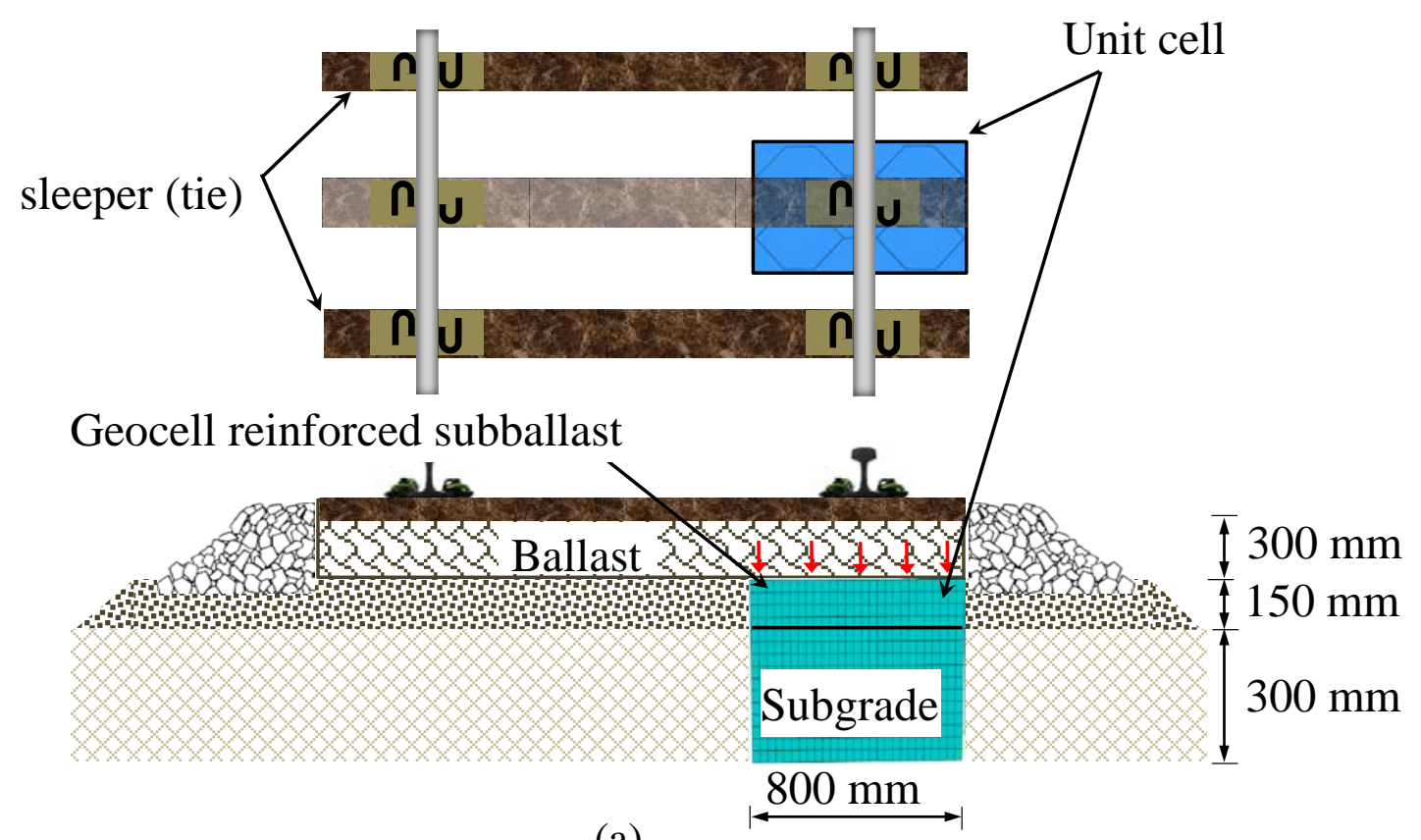

(a)

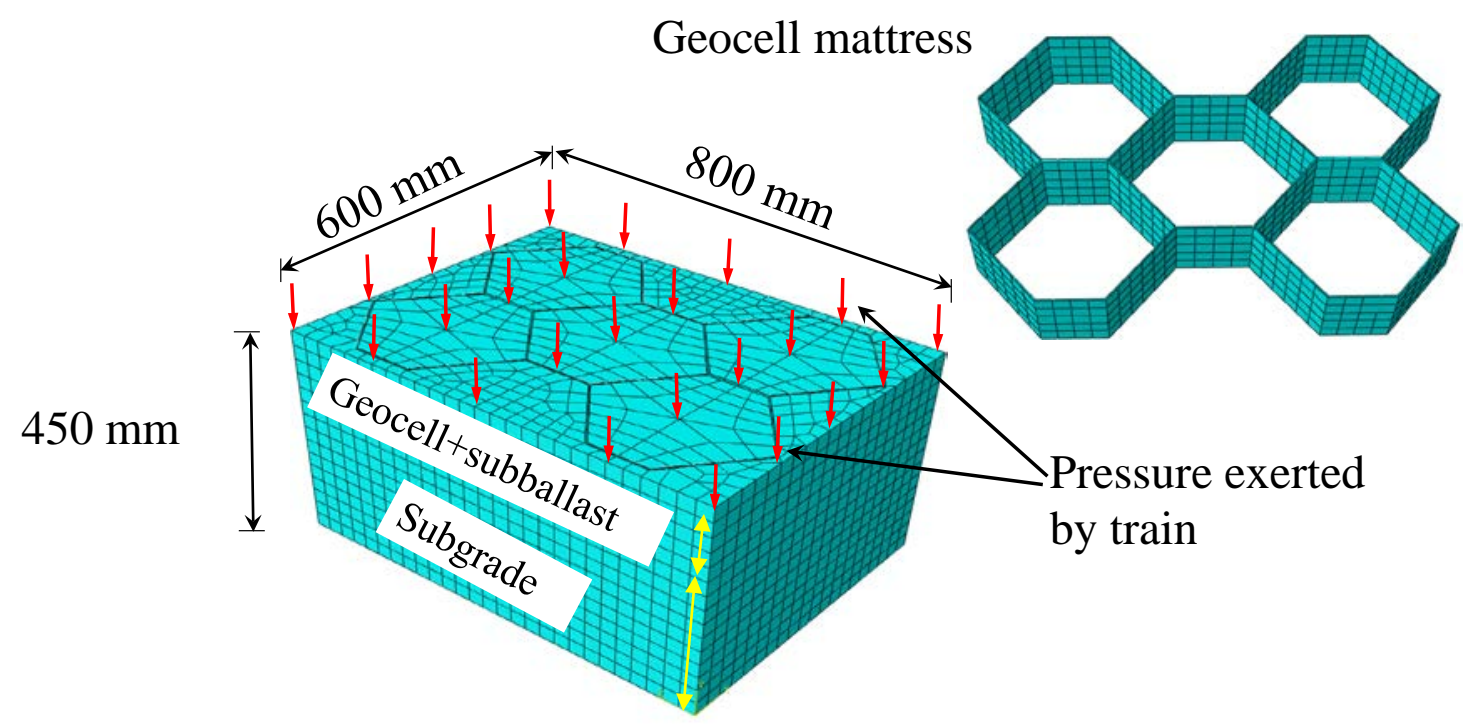

(b)

862

Figure 2. Finite element idealisation of typical rail environment.

864

865

866

867

868

869 


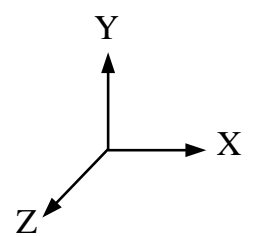

872

873

874

875

876

877

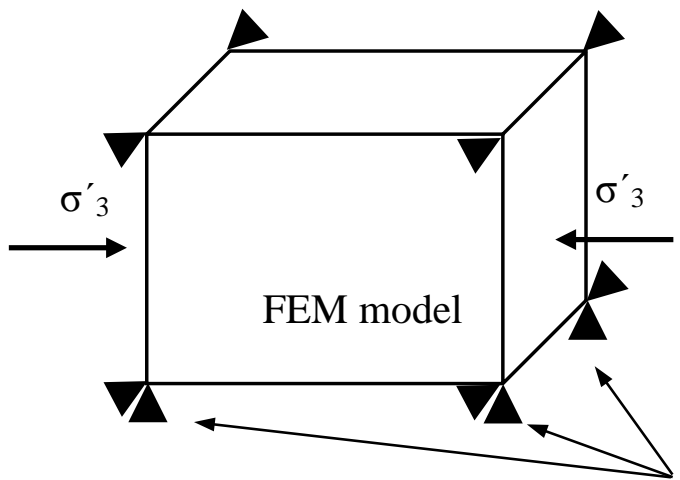

Displacement in the direction

878

to $\mathrm{Z}$ axis is restricted $\left(\varepsilon_{2}=0\right)$

(a)

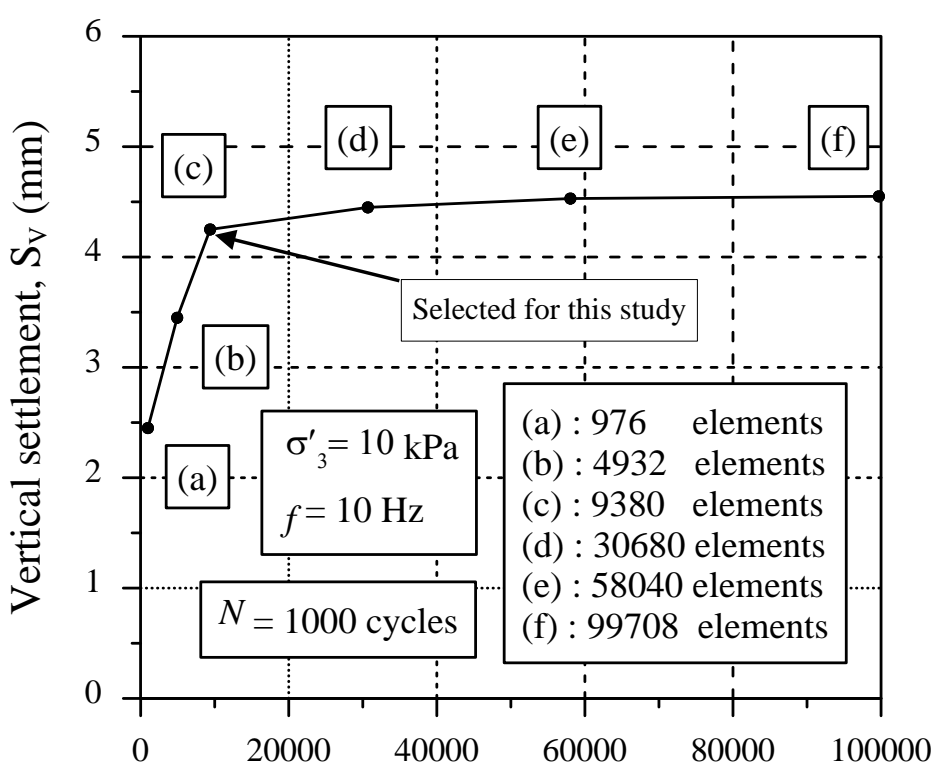

879

Number of elements

880

(b)

881 Figure 3. (a) Typical boundary condition for unit cell and (b) vertical settlement predicted by

882

FE model with different number of elements.

883

884

885

886 


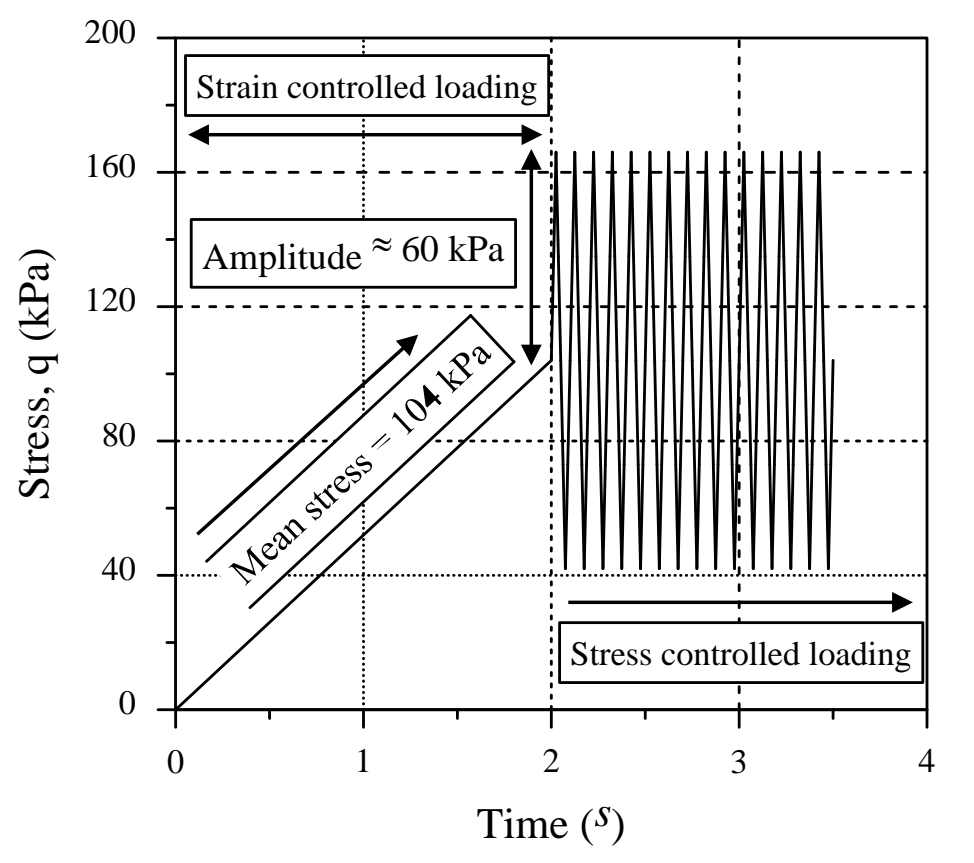

888

Figure 4. Schematic illustration of cyclic loading.

889

890

891

892

893

894 
Vertical settlement, $S_{V}(\mathrm{~m})$

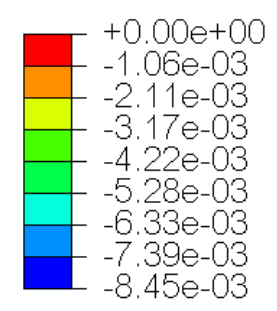

895

896

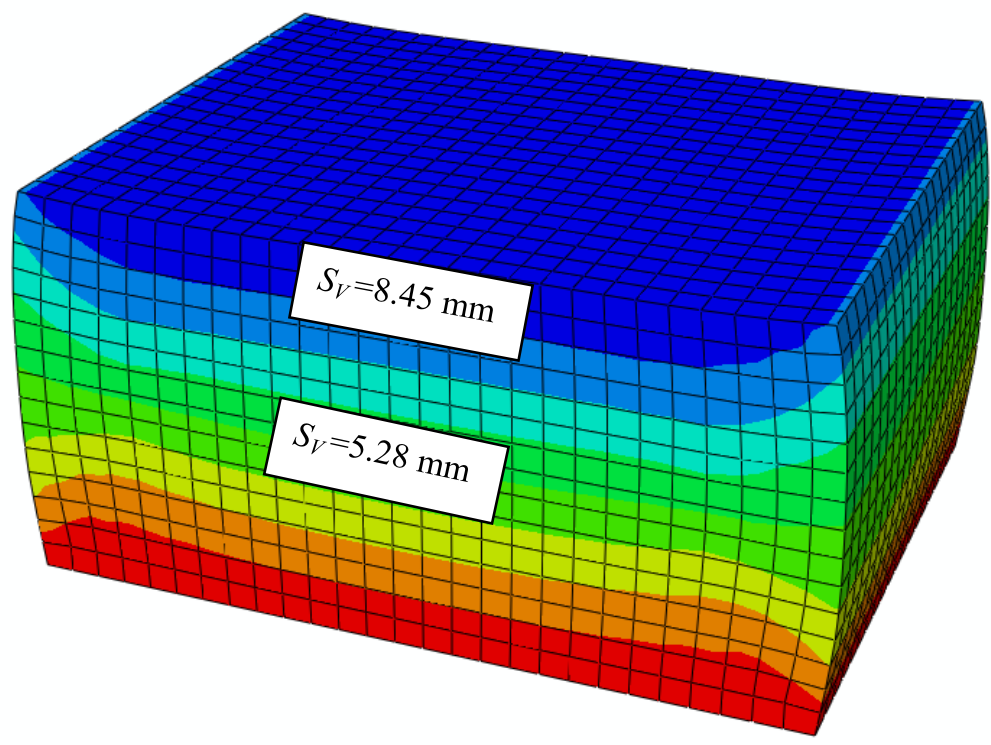

897

Vertical settlement, $S_{V}(\mathrm{~m})$

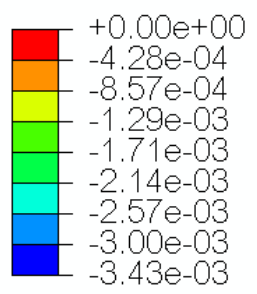

(a)

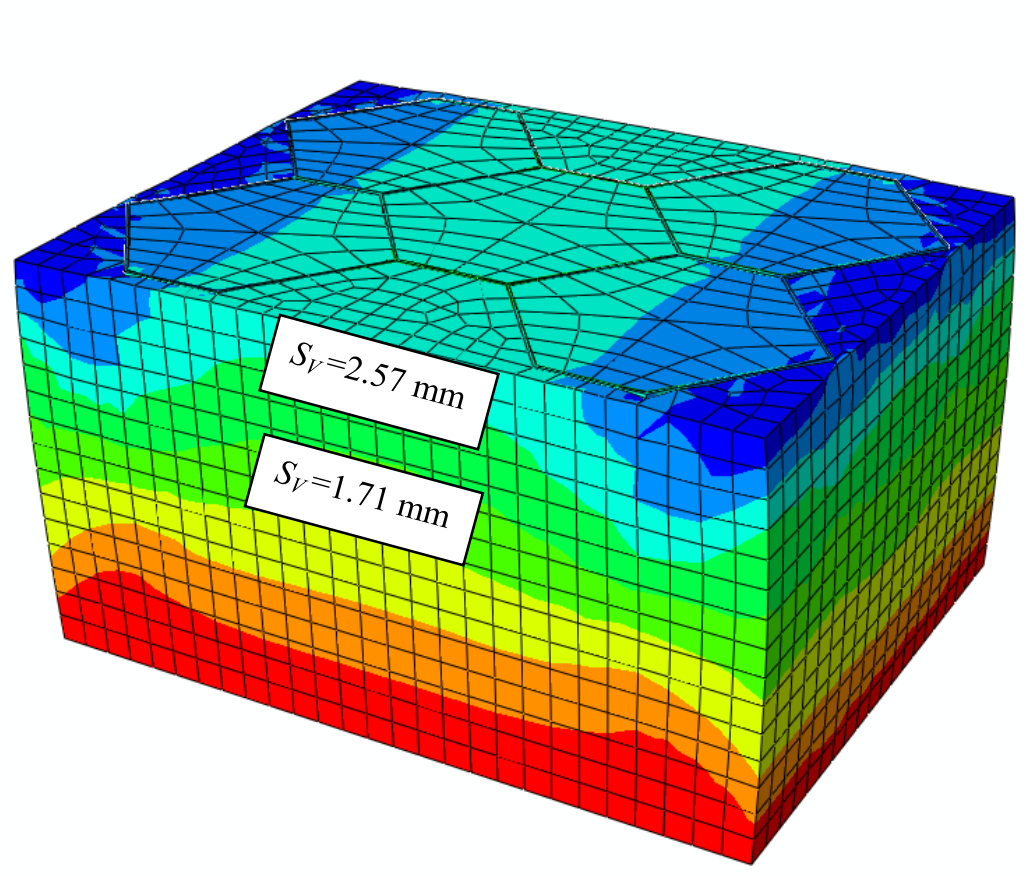

898

899

(b)

900 Figure 5. FEM predicted vertical settlements: (a) unreinforced; and (b) geocell-reinforced subballast. 


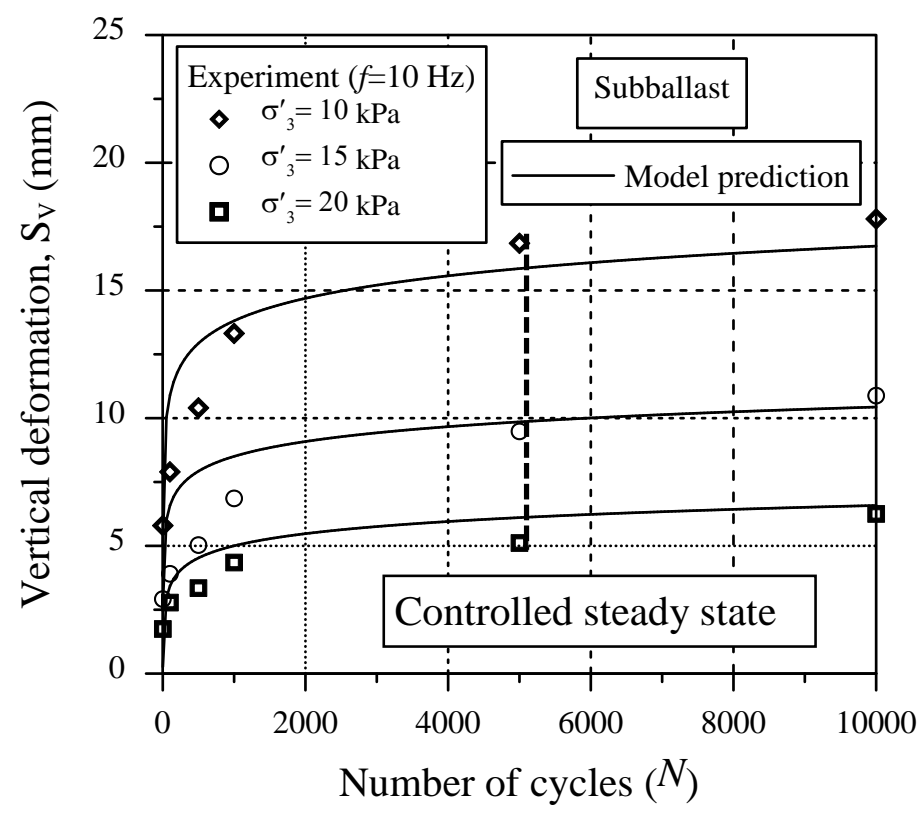

903

(a)

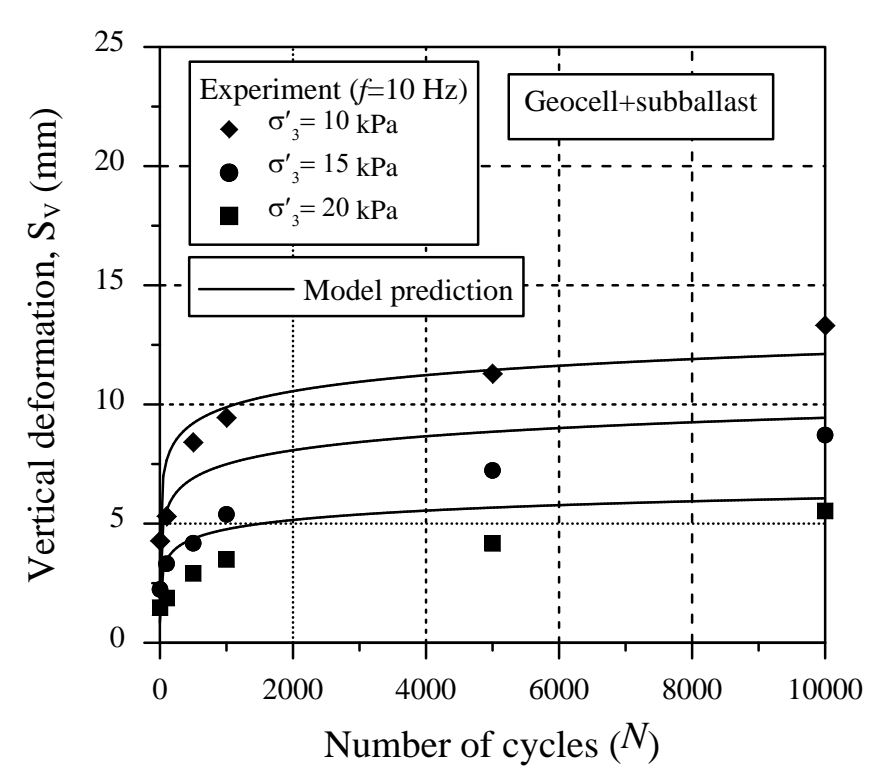

905

(b)

906 Figure 6. Vertical deformation of (a) unreinforced and (b) geocell- reinforced subballast

907 against number of cycles $(N)$ : laboratory measurements vs. model predictions.

908

909

910 


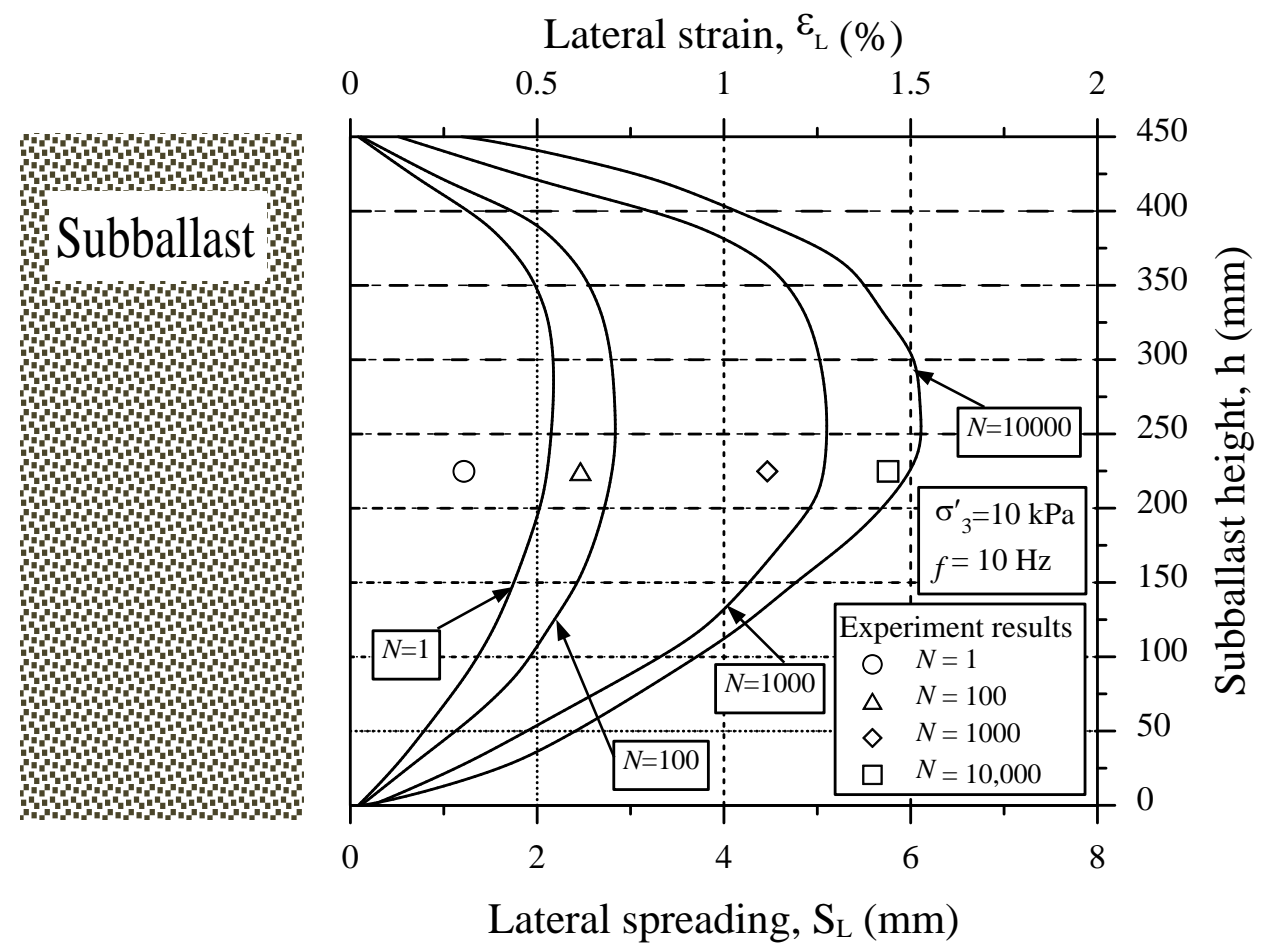


Lateral spreading $\mathrm{S}_{\mathrm{L}}(\mathrm{m})$
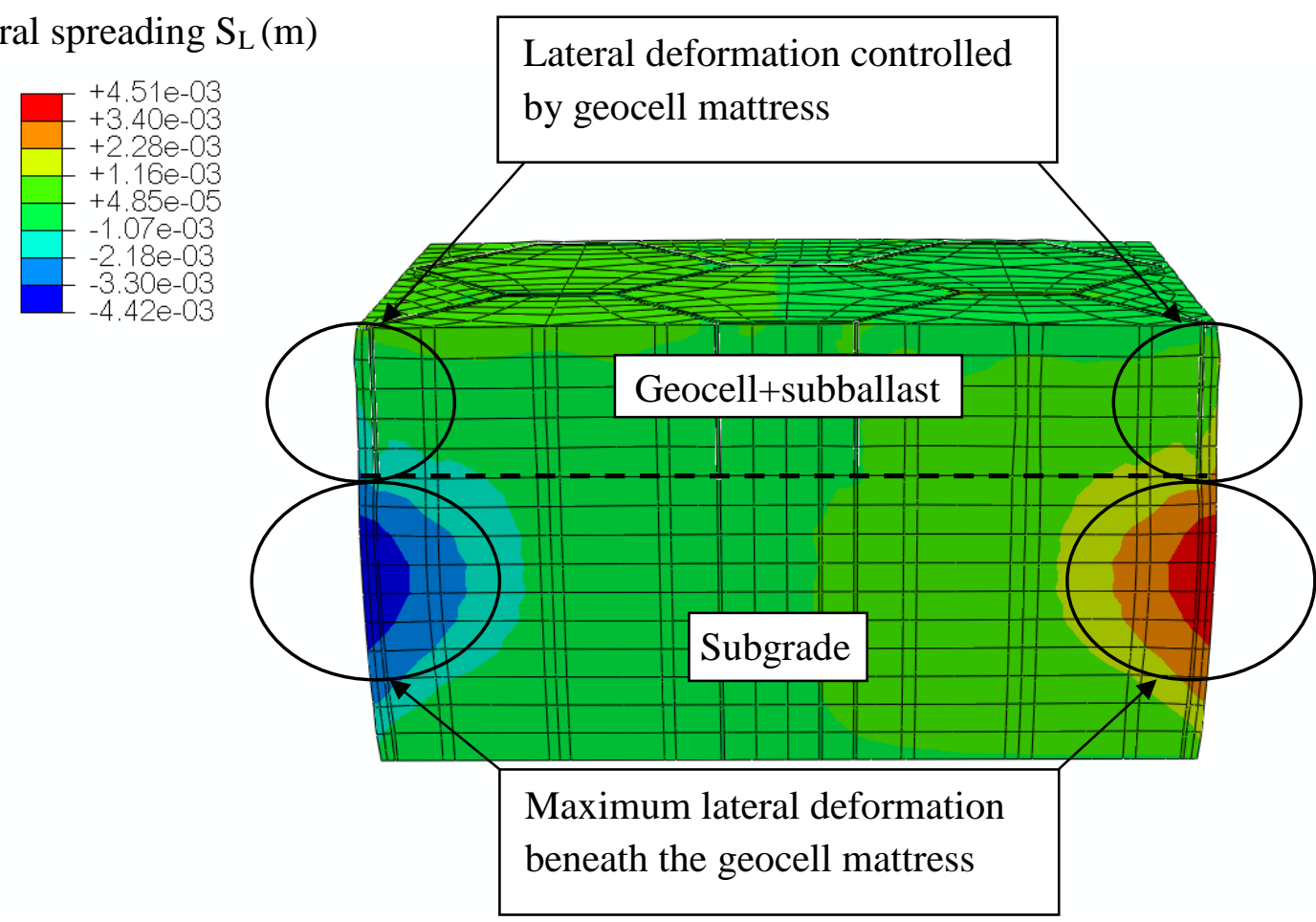

(a)

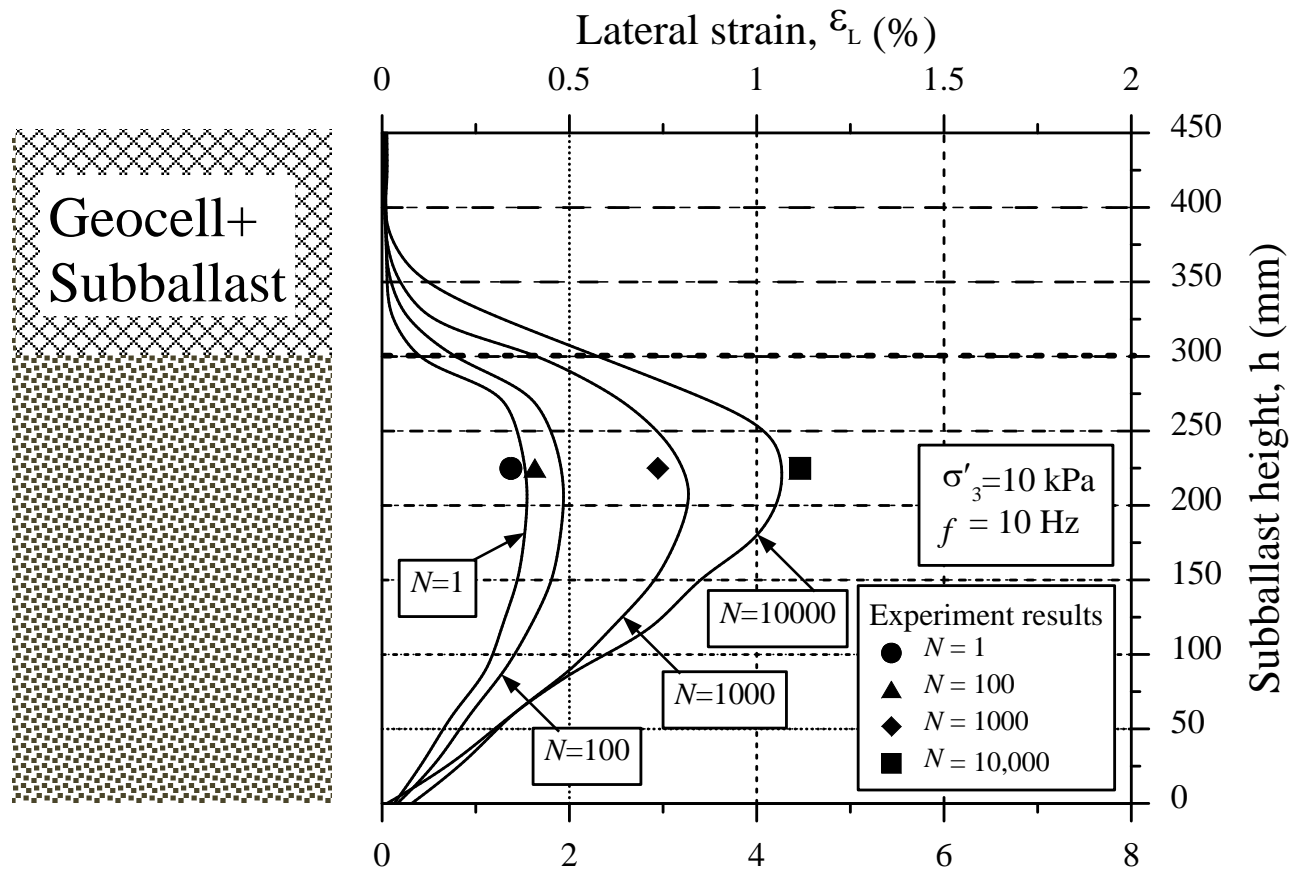

Lateral spreading, $\mathrm{S}_{\mathrm{L}}(\mathrm{mm})$

(b)

Figure 8. Typical lateral deformation profile of reinforced geocell-reinforced subballast (a) predicted by FEM and (b) at different depth and number of cycles. 


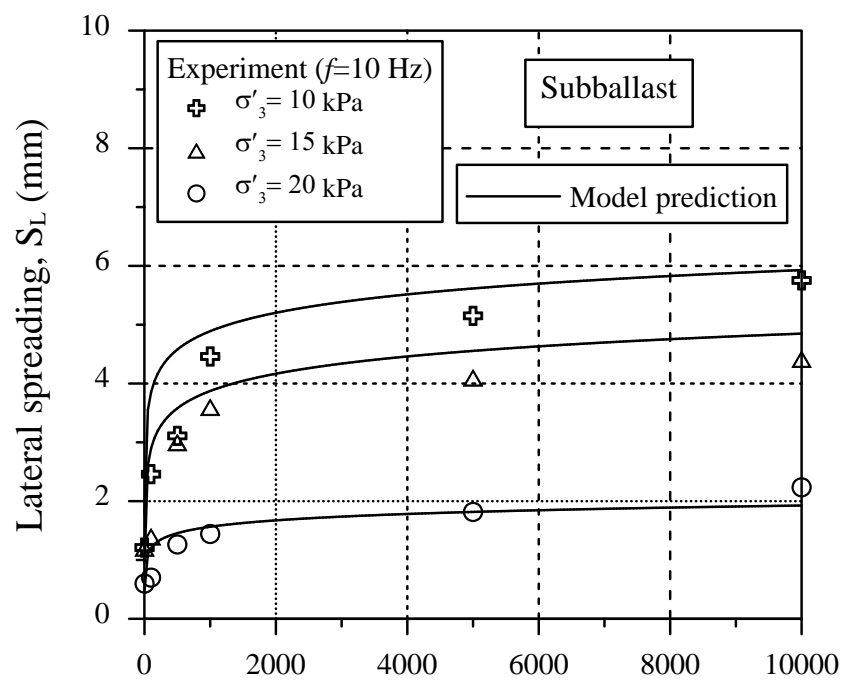

Number of cycles $(N)$

(a)

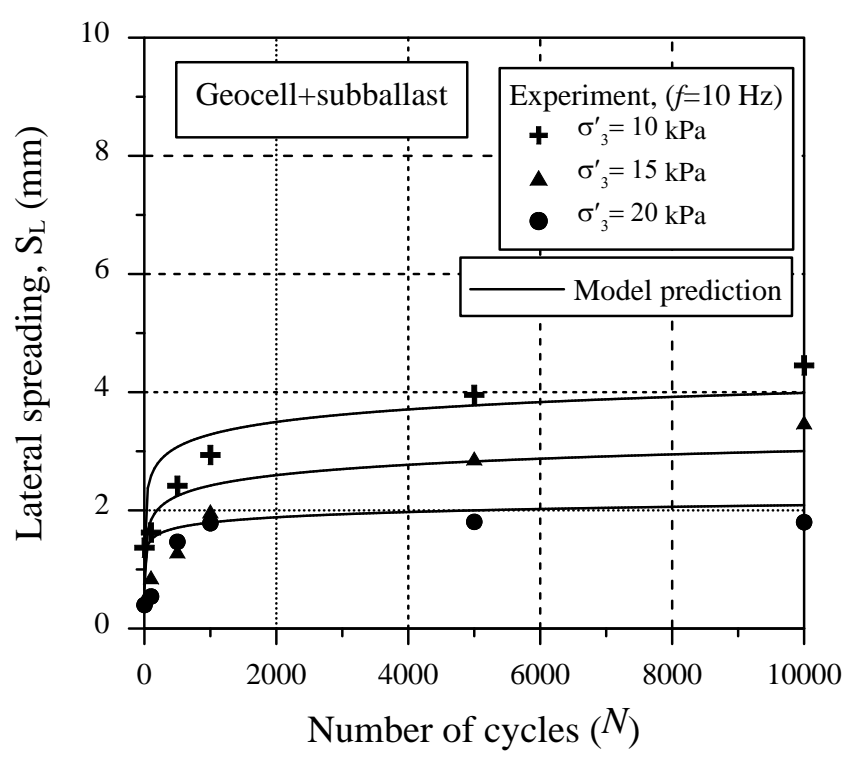

(b)

935 Figure 9. Lateral displacement of (a) unreinforced and (b) reinforced subballast again number of cycles $(N)$ : laboratory measurements vs. model predictions. 
Deviator stress, q $(\mathrm{kPa})$
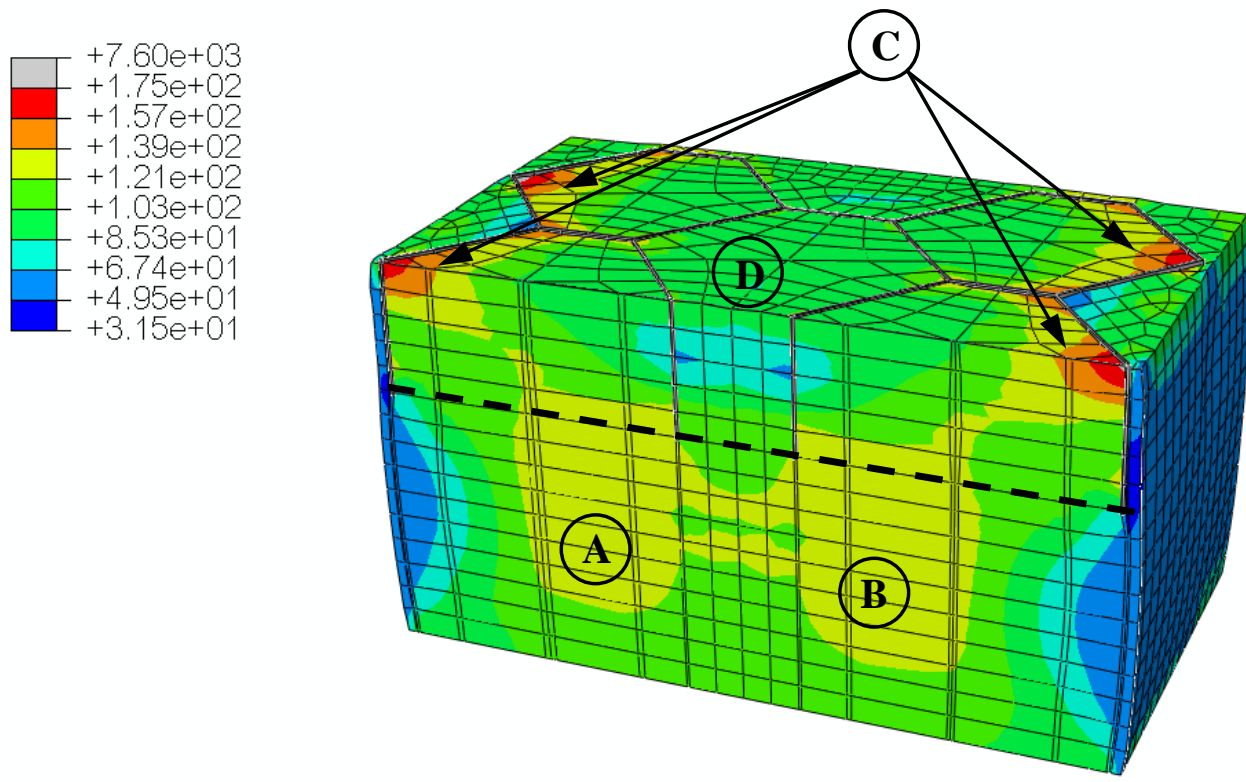

(a)
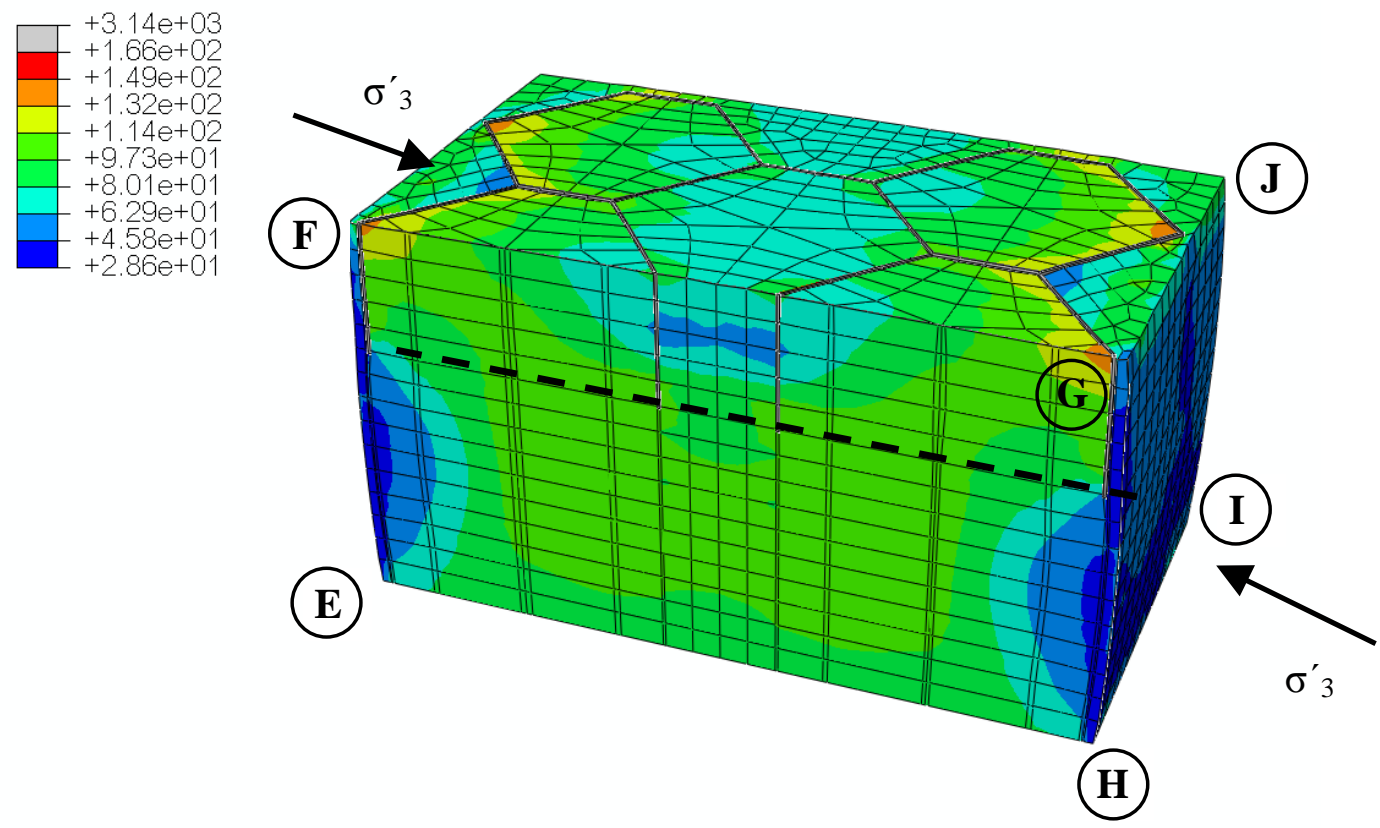

(b)

946 Figure 10. Stress distribution during (a) loading and (b) unloading of unit cell in a geocellreinforced subballast. 
Tensile stress, q (kPa)

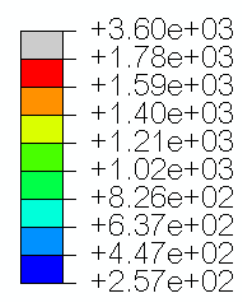

(B)

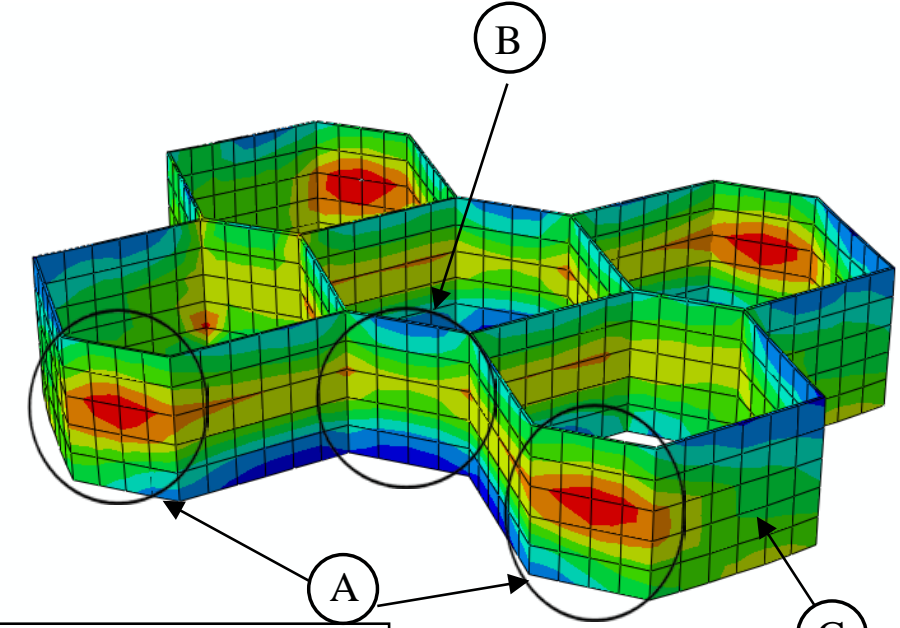

952

Area of geocell, which experiences

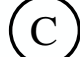

953 maximum stress

Minimum stress in direction parallel to intermediate stress, $\varepsilon_{2}=0$

954

$955 \quad$ (a)

Tensile stress, q ( $\mathrm{kPa})$
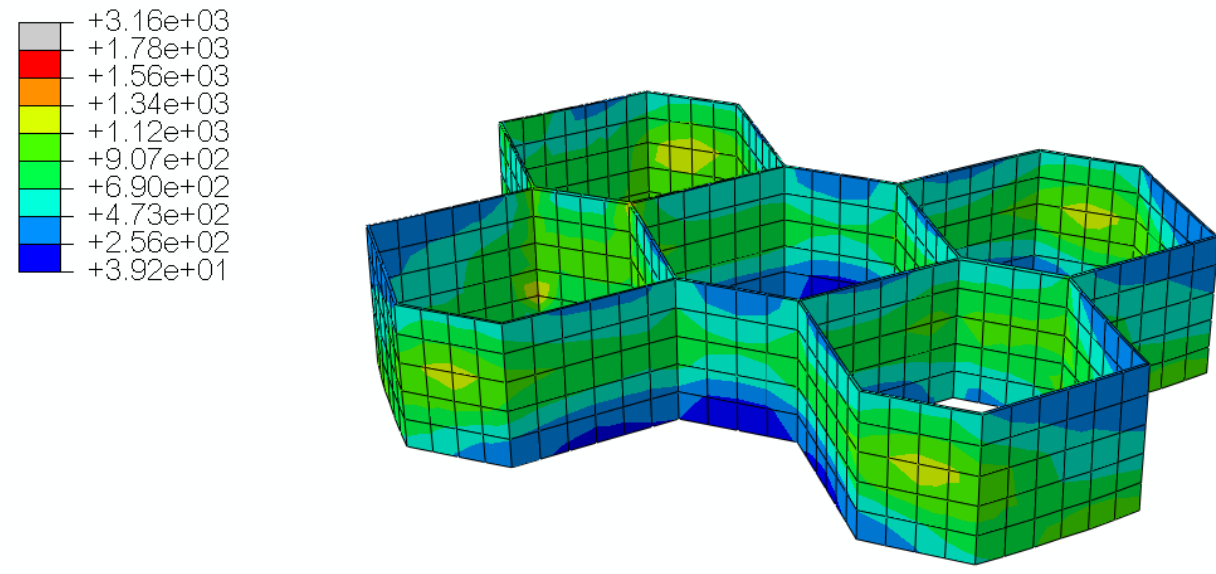

956

(b)

Figure 11. Tensile stress mobilized in geocell mattress (a) loading and (b) unloading stage 


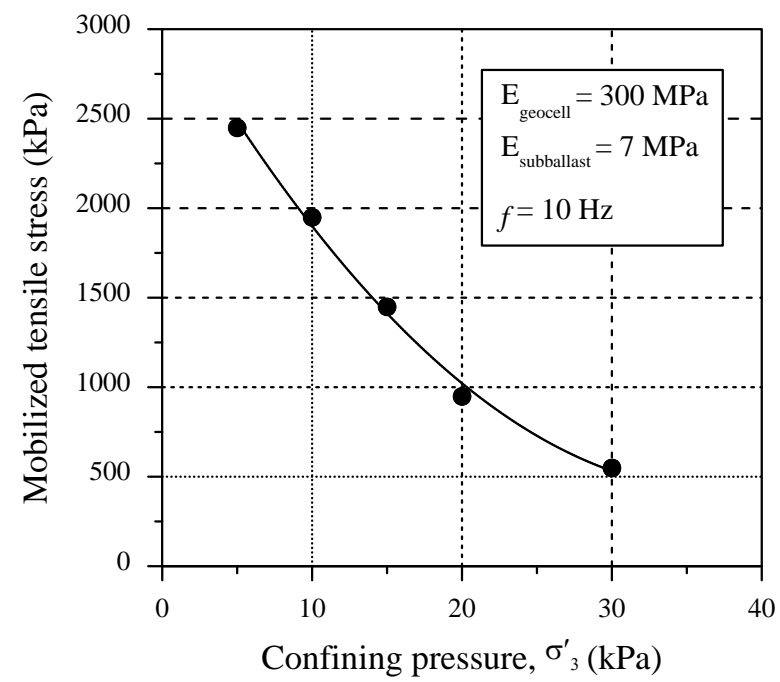

964 Figure 12. Mobilized tensile stress at the geocell in reinforced subballast at different

965 confining pressures $\sigma_{3}^{\prime}$.

966

967

968

969

970

971

972

973

974

975

976

977

978

979

980

981 


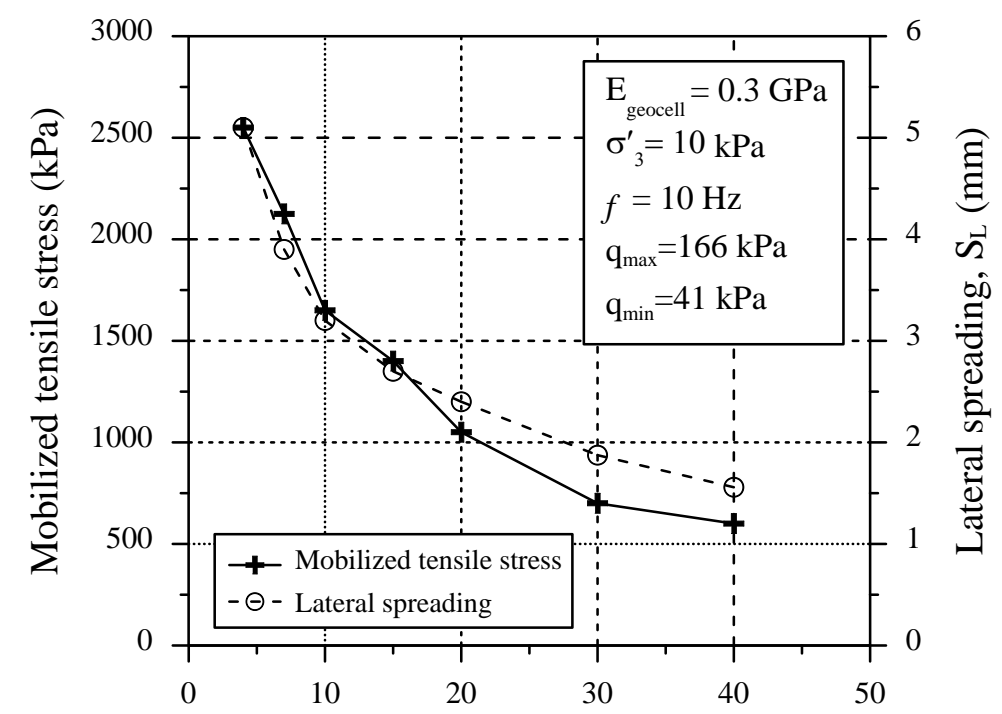

982

Subballast stiffness (MPa)

983

(a)

984

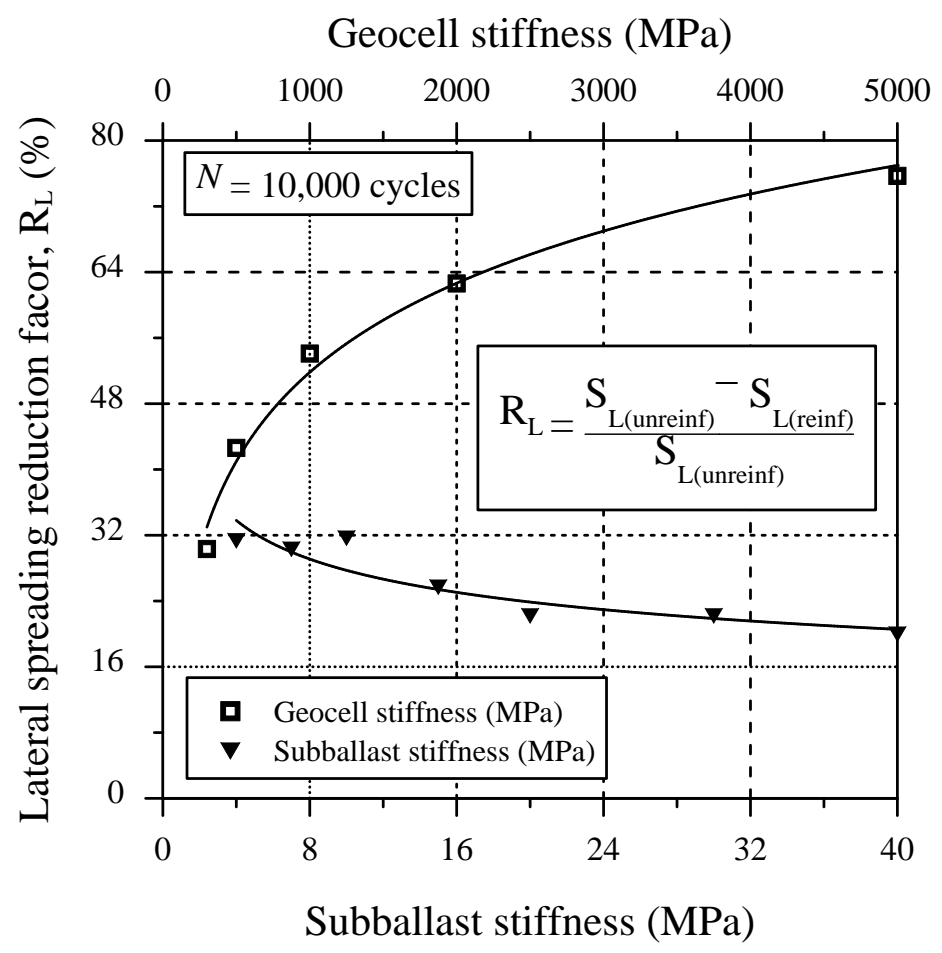

986

(b)

987 Figure 13. (a) Mobilized tensile stress at the geocell in reinforced subballast with different

988 stiffness and (b) reduction factor of lateral spreading for geocell-reinforced subballast. 


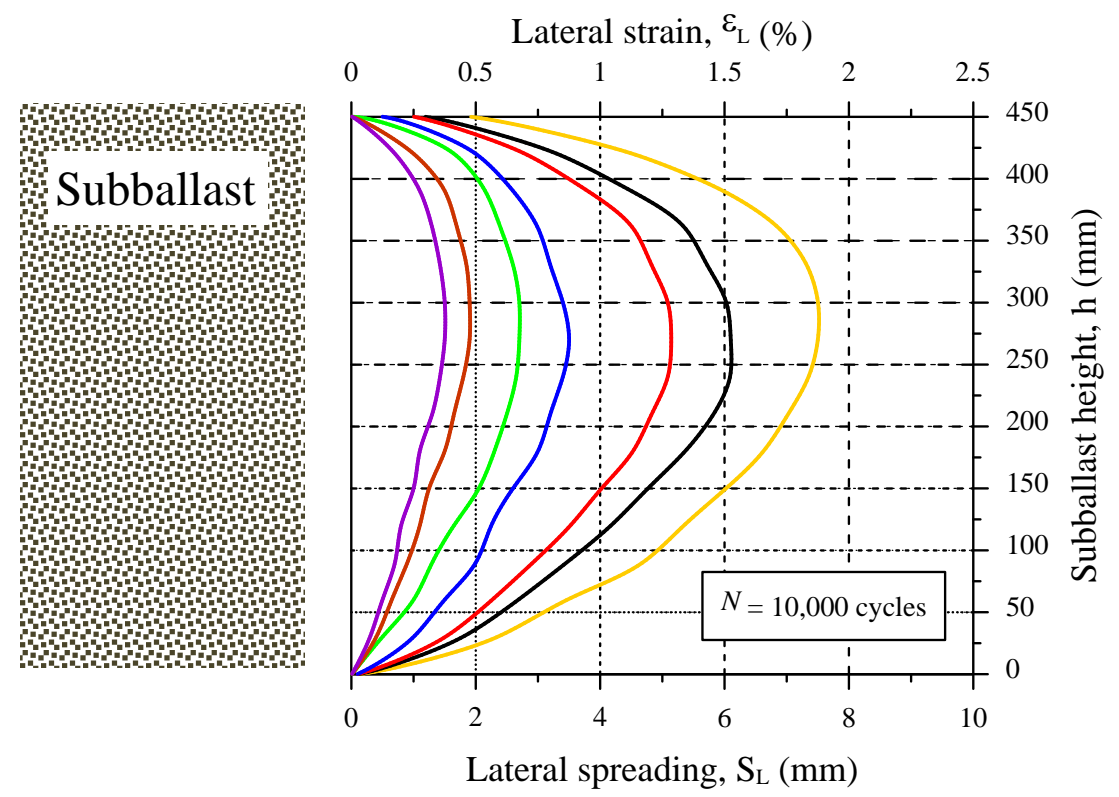

(a)

\begin{tabular}{rlr|} 
& Subballast strength \\
$\mathrm{E}=4 \mathrm{MPa}$ & $\mathrm{E}=20 \mathrm{MPa}$ \\
$\mathrm{E}=7 \mathrm{MPa}$ & $\mathrm{E}=30 \mathrm{MPa}$ \\
$\mathrm{E}=10 \mathrm{MPa}$ & $\mathrm{E}=40 \mathrm{MPa}$ \\
\hline $\mathrm{E}=15 \mathrm{MPa}$ &
\end{tabular}
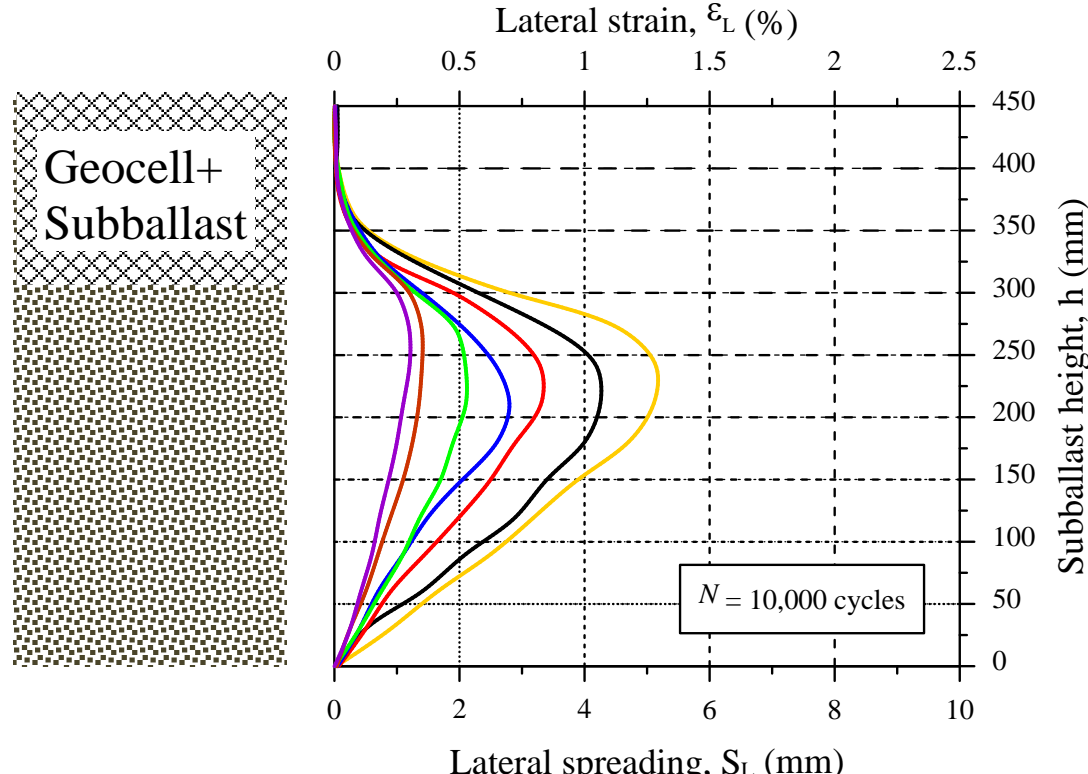

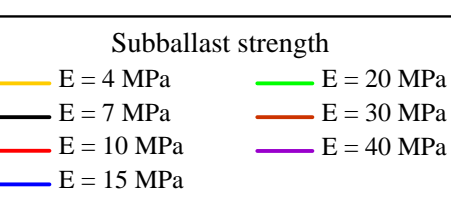

(b)

Figure 14. Lateral spreading of (a) unreinforced and (b) geocell-reinforced subballast at 


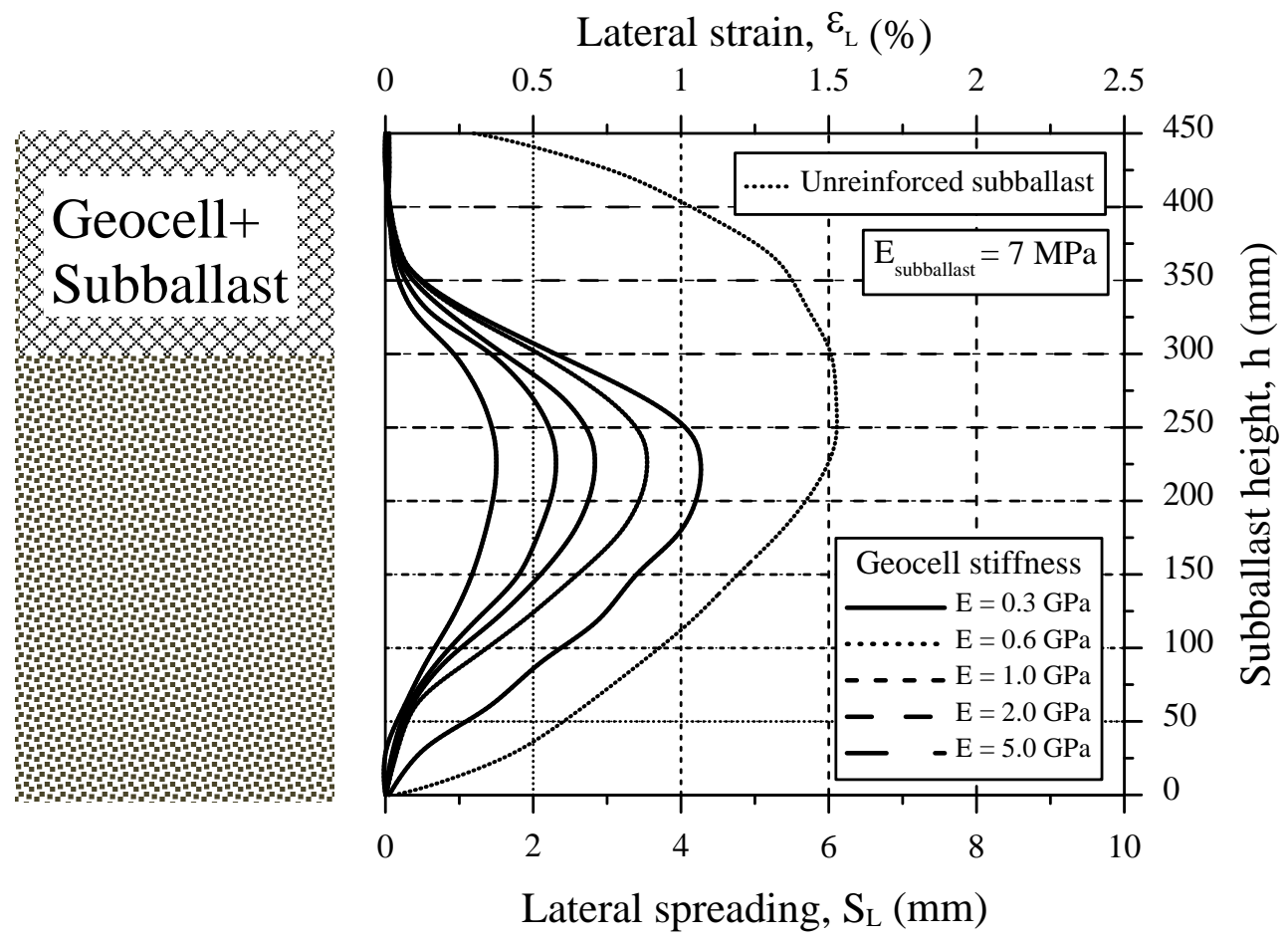

Figure 15.Comparison of lateral spreading of unreinforced and geocell-reinforced subballast

995

996

997

998

999

1000

1001

1002 


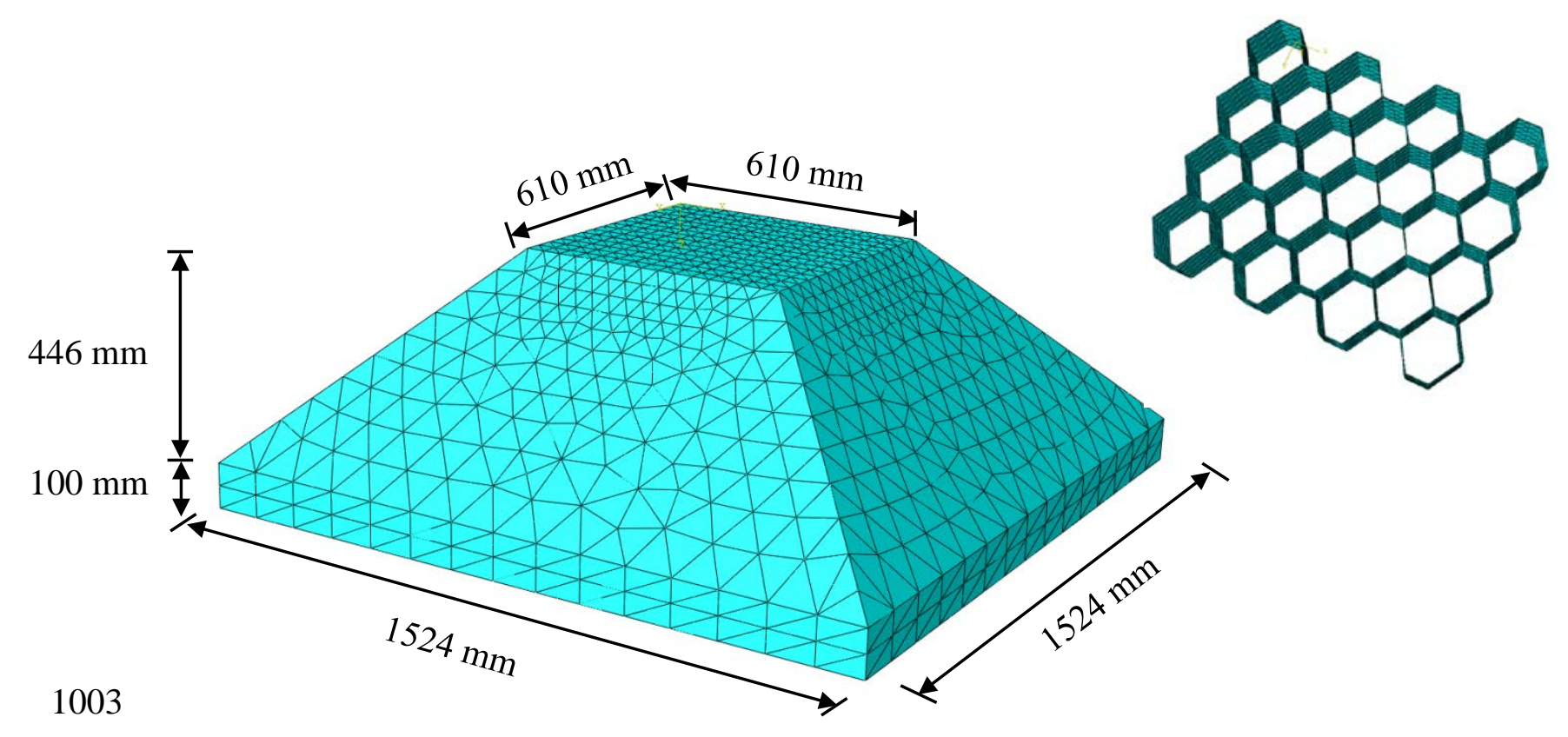

1004

1005 Figure 16. Typical FEM mesh of geometry of model and geocell mattress used for validation.

1006

1007

1008

1009

1010

1011

1012

1013

1014

1015 


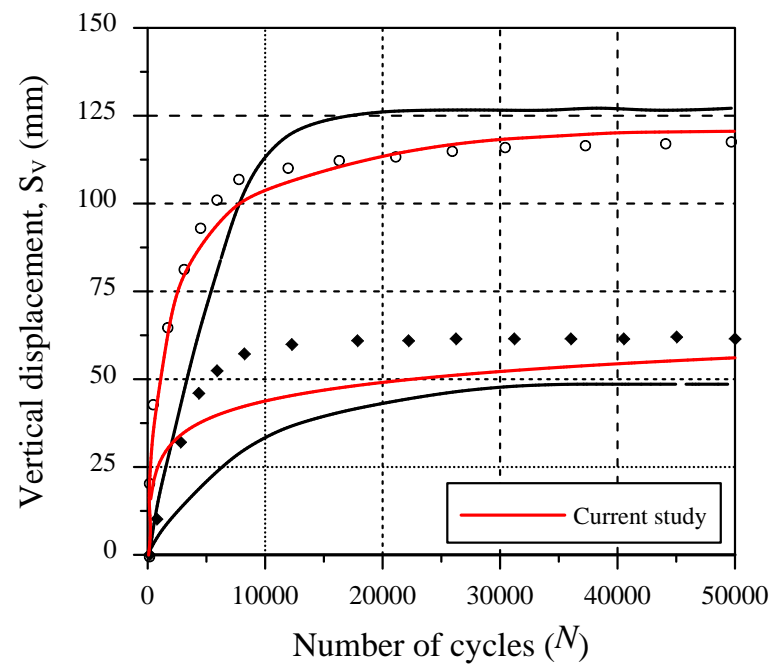

Leshchinsky and Ling (2013)

- - Unreinforced (Model prediction) O Unreinforced (Experiment)

(a)
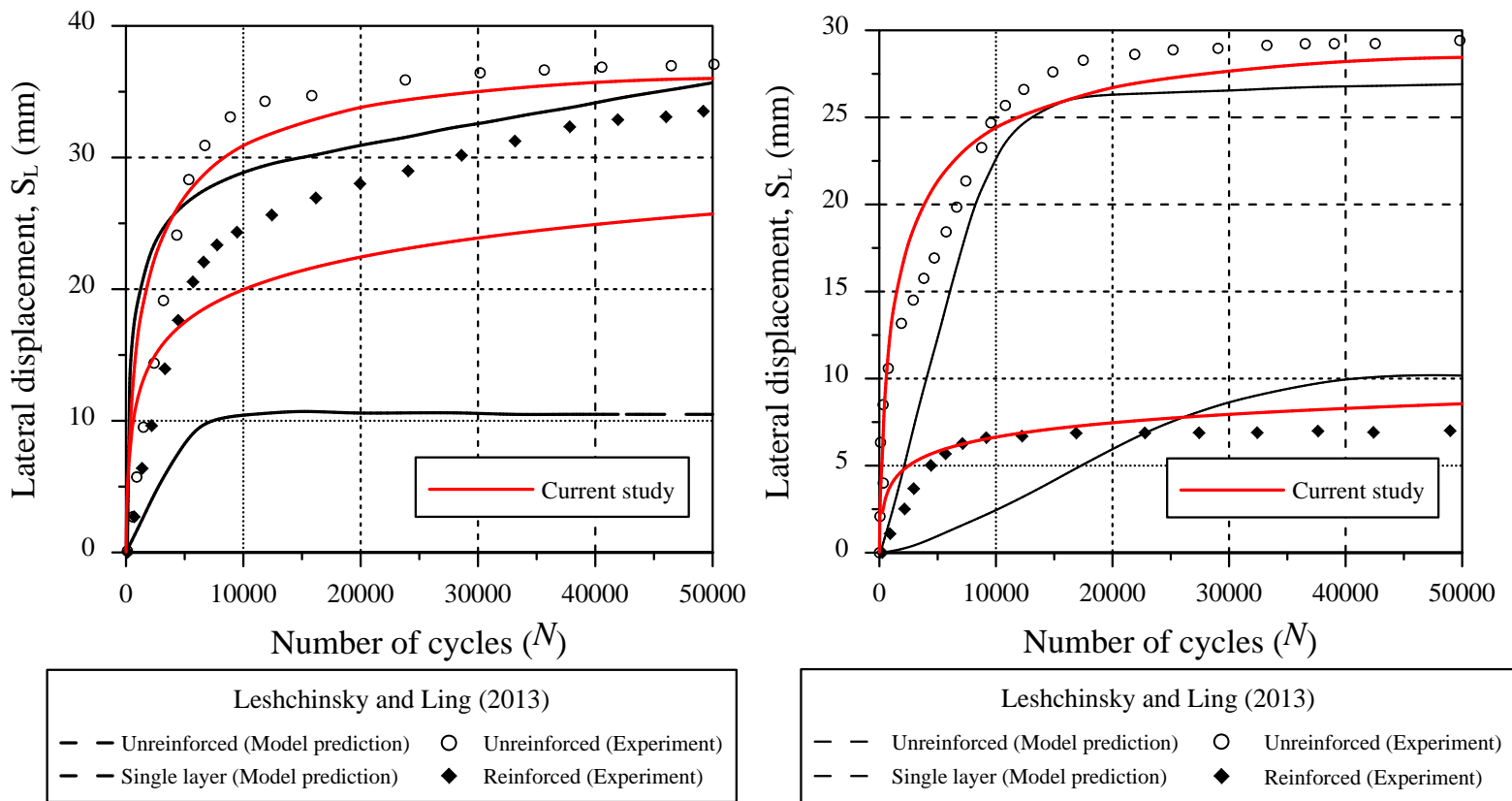

(c) 